\title{
DNA Methylation Dynamics in the Female Germline and Maternal-Effect Mutations That Disrupt Genomic Imprinting
}

\author{
Zahra Anvar 1,2@, Imen Chakchouk ${ }^{1,2}$, Hannah Demond ${ }^{3} \oplus$, Momal Sharif ${ }^{1,2} \oplus$, Gavin Kelsey ${ }^{3,4, *(1)}$ and \\ Ignatia B. Van den Veyver $1,2,5, *$
}

1 Department of Obstetrics and Gynecology, Baylor College of Medicine, Houston, TX 77030, USA; Zahra.Anvar@bcm.edu (Z.A.); imen.chakchouk@bcm.edu (I.C.); momal.sharif@bcm.edu (M.S.)

2 Duncan Neurological Research Institute, Texas Children's Hospital, Houston, TX 77030, USA

3 Epigenetics Programme, Babraham Institute, Cambridge CB22 3AT, UK; hannah.Demond@babraham.ac.uk

4 Centre for Trophoblast Research, University of Cambridge, Cambridge CB2 3EG, UK

5 Department of Molecular and Human Genetics, Baylor College of Medicine, Houston, TX 77030, USA

* Correspondence: gavin.kelsey@babraham.ac.uk (G.K.); iveyver@bcm.edu (I.B.V.d.V.); Tel.: +44-1223-496332 (G.K.); +832-824-8125 (I.B.V.d.V.)

check for updates

Citation: Anvar, Z.; Chakchouk, I.; Demond, H.; Sharif, M.; Kelsey, G.;

Van den Veyver, I.B. DNA

Methylation Dynamics in the Female Germline and Maternal-Effect Mutations That Disrupt Genomic Imprinting. Genes 2021, 12, 1214. https://doi.org/10.3390/ genes12081214

Academic Editor: Miguel Constancia

Received: 15 June 2021

Accepted: 3 August 2021

Published: 6 August 2021

Publisher's Note: MDPI stays neutral with regard to jurisdictional claims in published maps and institutional affiliations.

Copyright: (c) 2021 by the authors. Licensee MDPI, Basel, Switzerland. This article is an open access article distributed under the terms and conditions of the Creative Commons Attribution (CC BY) license (https:/ / creativecommons.org/licenses/by/ $4.0 /)$.

\begin{abstract}
Genomic imprinting is an epigenetic marking process that results in the monoallelic expression of a subset of genes. Many of these 'imprinted' genes in mice and humans are involved in embryonic and extraembryonic growth and development, and some have life-long impacts on metabolism. During mammalian development, the genome undergoes waves of (re)programming of DNA methylation and other epigenetic marks. Disturbances in these events can cause imprinting disorders and compromise development. Multi-locus imprinting disturbance (MLID) is a condition by which imprinting defects touch more than one locus. Although most cases with MLID present with clinical features characteristic of one imprinting disorder. Imprinting defects also occur in 'molar' pregnancies-which are characterized by highly compromised embryonic development-and in other forms of reproductive compromise presenting clinically as infertility or early pregnancy loss. Pathogenic variants in some of the genes encoding proteins of the subcortical maternal complex (SCMC), a multi-protein complex in the mammalian oocyte, are responsible for a rare subgroup of moles, biparental complete hydatidiform mole (BiCHM), and other adverse reproductive outcomes which have been associated with altered imprinting status of the oocyte, embryo and/or placenta. The finding that defects in a cytoplasmic protein complex could have severe impacts on genomic methylation at critical times in gamete or early embryo development has wider implications beyond these relatively rare disorders. It signifies a potential for adverse maternal physiology, nutrition, or assisted reproduction to cause epigenetic defects at imprinted or other genes. Here, we review key milestones in DNA methylation patterning in the female germline and the embryo focusing on humans. We provide an overview of recent findings regarding DNA methylation deficits causing BiCHM, MLID, and early embryonic arrest. We also summarize identified SCMC mutations with regard to early embryonic arrest, BiCHM, and MLID.
\end{abstract}

Keywords: oocyte; epigenetics; genomic imprinting; DNA methylation; subcortical maternal complex; embryo arrest; infertility; epimutations

\section{Introduction}

DNA methylation is one of the best-studied epigenetic modifications and plays an essential role in mammalian development [1]. It is thought to be involved in multiple processes including the regulation of gene expression, heterochromatin formation, and genome integrity. DNA methylation is deposited by the de novo DNA methyltransferases. DNA methyltransferase 3A and 3B (DNMT3A and DNMT3B) are the major de novo DNA methyltransferases, and DNMT3L, which does not possess enzymatic activity, stimulates DNMT3A and DNMT3B activity by binding to their catalytic domains [2]. DNA 
methylation is maintained during replication by the maintenance DNA methyltransferase 1 (DNMT1) in collaboration with ubiquitin-like with PHD and RING finger domains 1 UHRF1 $[3,4]$. However, DNMT1 also contributes to de novo DNA methylation in mouse oocytes [5].

Sexual reproduction in mammals requires the reprogramming of methylation marks. Nearly all DNA methylation is removed through a comprehensive reprogramming process in primordial germ cells (PGCs), which are the gamete precursors. This step is referred to as erasure (Figure 1). Subsequently, new methylation patterns are re-established in the germ cells in an asymmetrical fashion in the male and female germline, which give rise to highly specialized gametes ready for fertilization [6]. This step is called establishment (Figure 1). Studies in mice have demonstrated that in the male germline, de novo methylation begins prenatally in mitotically arrested prospermatogonia and is completed after birth $[7,8]$. The mature sperm has a uniform methylation pattern similar to somatic cells: the genome is ubiquitously hypermethylated with the exception of CG-rich regions of the genome, called CpG islands, most of which remain unmethylated $[9,10]$. In female germ cells, the establishment of methylation takes place after birth in growing oocytes arrested at meiotic prophase I. The mature oocyte in both mice and humans has a comparatively low overall methylation level that is almost exclusively restricted to transcribed gene bodies but about $10 \%$ of $\mathrm{CpG}$ islands is also hypermethylated [11-14].

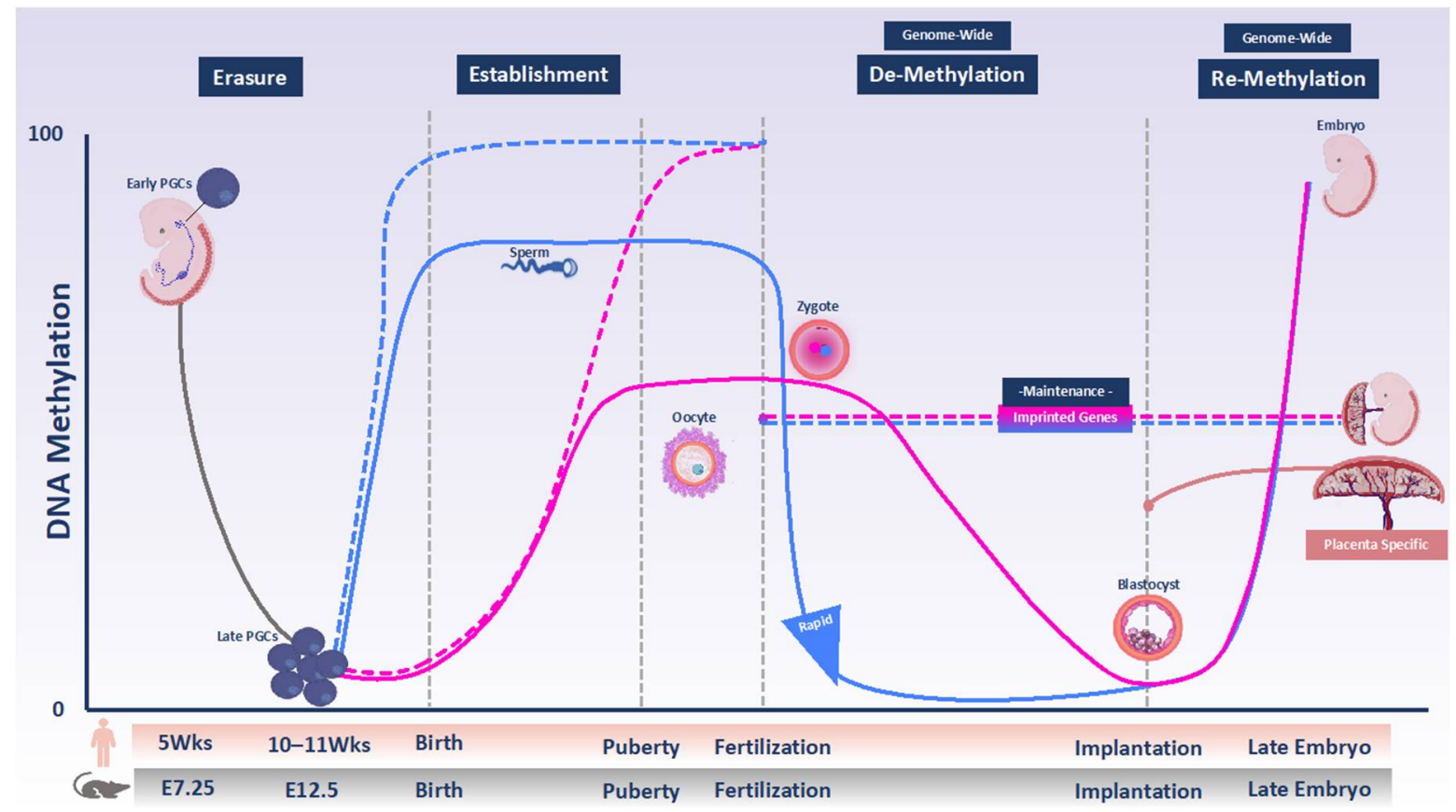

Figure 1. DNA methylation programming and reprogramming during development in humans and mice. DNA methylation is globally erased in primordial germ cells (PGCs) derived from epiblast during their proliferation and migration to the genital ridges (solid gray line). Therefore, de novo DNA methylation subsequent takes place on a largely blank slate during male and female gametogenesis. In the male, new methylation is established from soon after demethylation and is almost completed by the time of birth (solid blue line). In females, there is no gain of methylation until after birth. Growing oocytes arrested in the first meiosis prophase gain methylation between birth and puberty, as well as in adult life (solid pink line). Maternally and paternally imprinted DMRs become differentially methylated in gametes over the same time window (dashed pink and blue lines, respectively). After fertilization, the parental genomes undergo genome-wide demethylation, which does not include imprinted DMRs (dashed combined pink and blue lines). The timing and extent of demethylation are different for the two parental genomes. The paternal genome is rapidly demethylated in part via TET proteins activity (solid blue line). The maternal genome is protected against TET activity and undergoes passive demethylation following DNA replication (solid pink line). By the time of implantation, the genome-except for imprinted DMRs-undergoes re-methylation events that are necessary for cell-lineage determination (combined red and blue lines). Placenta-specific imprinting that is present only in humans is shown with the solid coral orange line. 
Following fertilization, the genome of the mouse zygote undergoes another reprogramming wave (Figure 1). The timing and mode of reprogramming differ between the parental genomes. Most of the paternal genome is actively demethylated: Demethylation occurs rapidly and has been observed even before pronuclear fusion [15]. In part, it is mediated by Ten-Eleven Translocation 3 (TET3)-driven oxidation of 5-methylcytosine $(5 \mathrm{mC})$ to 5-hydroxymethylcytosine $(5 \mathrm{hmC})$ [16]. Conversely, maternal-genome methylation is largely protected at this stage and is slowly diluted during DNA replication, mainly because of the absence of DNMT1 activity $[15,17]$. However, it has been shown in both human and mouse that the maternal genome is subject to both de novo methylation and hydroxylation events $[18,19]$.

In mammals, genomic imprinting is an important consequence of sexual reproduction. Genomic imprinting is an epigenetically regulated process in which DNA methylation marking in a parent-of-origin-specific manner of one allele of a gene or its control element causes monoallelic expression [20]. Many imprinted genes are organized in clusters and each cluster is regulated by an imprinting control region (ICR). An ICR that acquires monoallelic DNA methylation in the germline serves as a primary imprinting mark and is, thus, referred to as germline differentially methylated region (gDMR). These primary gDMRs escape embryonic reprogramming and their parent-of-origin dependent mono-allelic DNA methylation persist in somatic tissues. This step is called maintenance (Figure 1) [21].

Altered monoallelic expression of imprinted genes caused by genetic or epigenetic defects is associated with imprinting disorders [22]. In other words, any disruption in erasure, establishment or maintenance of imprints can result in an imprinting disorder. For example, the failure to establish imprints during female gametogenesis or maintain them is shown to be associated with BiCHM, which is an aberrant human pregnancy characterized by placental overgrowth and absence of embryonic tissues $[23,24]$. The results from studies of patients with imprinting disorders suggest that maintenance of gDMR methylation during post-fertilization reprogramming requires the expression of maternal-effect genes in the oocyte and early embryo. Several of these encode proteins of the subcortical maternal complex (SCMC). The SCMC is a multi-protein structure present in the mammalian oocyte and early embryo involved in several important cellular processes in the egg-to-zygote transition. Maternal ablation of some SCMC members impairs embryonic development and is implicated in adverse reproductive outcomes, including pregnancy loss and hydatidiform moles as well as live-born children with multi-locus imprinting disturbances (MLID) [25-29]. In the latter, an imprinting disorder is accompanied by methylation defects at multiple ICRs.

This review investigates the relationship between DNA methylation deficits and abnormal early development in humans, focusing on the female germline. Therefore, we first describe the DNA methylation landscape in human PGCs, oocytes, pre-implantation embryos, and extra-embryonic lineages in detail. Second, by focusing on the role of the SCMC, we address the current understanding of defective DNA methylation reprogramming in relation to three forms of the restricted developmental disorder: MLID, BiCHM, and early embryonic demise. We also summarize SCMC mutations that impair development by causing the above conditions. Although MLID and BiCHM are rare genetic disorders of imprinting, knowledge of their etiology, together with a full understanding of the mechanisms of imprint establishment and maintenance, are key to recognizing the potential that factors, such as adverse maternal physiology, nutrition or other exposures, and assisted reproduction procedures, have for disrupting the fidelity of imprinting and precipitating lifelong epigenetic errors.

\section{DNA Methylation Programming and Reprogramming in the Female Germline and Early Embryo}

\subsection{Primordial Germ Cells and Oocytes}

Human PGCs are specified at approximately two weeks post-fertilization (pf), after which they migrate from the yolk sac wall and colonize the gonadal ridge between $3-5$ weeks pf. Here, they undergo substantial proliferation before sexual differentiation [30]. 
Until week 5, the genomes of PGCs are highly methylated (Figure 1), but must be reprogrammed to give rise to functional gametes. DNA methylation reprogramming at this stage is concomitant with the downregulation of DNMT3A, DNMT3B, and UHRF1, the DNMT1 accessory factor, and the upregulation of TET1 and TET2 [31]. The lowest DNA methylation level in the human genome is achieved after this reprogramming at 10-11 weeks pf. At this stage, global DNA methylation levels were reported to be $8 \%$ in male PGCs at 11 weeks and $6 \%$ in female PGCs at 10 weeks (Figure 1) [32,33].

The timing of methylation establishment during oogenesis in humans has recently been described by Yan et al. [34]. Single-cell multi-omics sequencing revealed that de novo methylation occurs in growing oocytes, similar to what has been described in the mouse. De novo methylation correlates with chromatin accessibility and transcription [34]. Although the timing and pattern of de novo methylation during human oogenesis may be analogous to those in mice, the roles of DNMTs may differ. In mice, knockout studies have shown that de novo methylation in the oocyte requires DNMT3A and its co-factor DNMT3L, but not DNMT3B [35,36]. Interestingly, transcripts for DNMT3B are expressed 10-fold higher than DNMT3A in human oocytes and DNMT3L is not expressed at all. Therefore, it has been suggested that DNMT3B, or an oocyte-specific isoform of DNMT3B, may replace DNMT3L in human oocytes as a partner for DNMT3A [13,37]. In the Yan et al. study, DNMT1 and DNMT3A transcripts were found in both growing and fully grown oocytes, while DNMT3B and UHRF1 were mostly expressed in mature oocytes [34].

Mature human oocytes (meiotic metaphase II, MII) show an intermediate level of genomic CpG methylation with a mean of 53.8\% [13,38]. Like mouse oocytes, the human oocyte has a bimodal DNA methylation pattern, with broad hypermethylated and hypomethylated domains $[13,34,39]$. The majority of hypermethylated domains correspond to actively transcribed gene bodies and gene body methylation levels correlate with transcription levels. The remainder of the genome remains largely unmethylated, indicating that active transcription may drive DNA methylation in human oocytes in a similar manner as in the mouse $[13,34,38,40]$. However, unlike in mice, promoter accessibility positively correlates with gene-body methylation in human oocytes. Although comparable numbers of transcripts are detected in mouse and human oocytes, more genes are hypermethylated ( $>75 \%$ methylation) in human oocytes. In addition, a greater number of non-transcribed intergenic regions that become methylated in human growing oocytes have been identified [34]. In humans, follicle growth is an extended process: almost 120 days are required for primordial follicles to reach the preantral follicle stage and a further 85 days to reach the ovulatory follicle stage [41]. The relatively long time over which DNMTs are active has been suggested as a possible cause of methylation of a greater proportion of genes in humans compared to mice [42]. Alternatively, there may be some differences in the chromatin determinants of de novo methylation or expression levels of necessary chromatin factors.

In their exploration of the oocyte and sperm methylome, Okae and colleagues identified differentially methylated regions (DMRs) between male and female gametes (defined as $\geq 80 \%$ methylation present in only one gamete) and described 29,424 regions that are exclusively methylated in the oocyte genome [13]. These oocyte-specific hypermethylated domains localize primarily to intragenic regions and are enriched for CpG islands (CGIs), gDMRs, gene promoters, gene bodies, and transposable elements such as short interspersed nuclear elements (SINEs), the evolutionary younger superfamily of Alu elements, and long interspersed nuclear elements (LINEs) [19,38].

\subsection{Preimplantation Embryo}

Soon after fertilization, the genome undergoes global demethylation (Figure 1). The removal of epigenetic marks inherited from gametes leads to the restoration of developmental potency in the zygote and adjusts the parental epigenomes of the embryo [43]. This global wave of epigenetic reprogramming is part of the egg-to-embryo transition, which also includes zygotic genome activation (ZGA) and the removal of maternal factors. The initial cell divisions and growth of the developing new embryo rely entirely on 
stored proteins and RNAs that are expressed from the maternal genome in the developing oocyte. The genes from which these RNAs are expressed are referred to as maternal-effect genes as they are transcribed from the maternal genome before fertilization, but their products are essential for the developing embryo until its genome is transcribed. After fertilization, the maternally provided transcripts and proteins gradually degrade while ZGA (which is completed at the four to the eight-cell stage in human embryos and at the two-cell stage in mouse embryos) encompasses the beginning of embryonic transcription, which will gradually take over control of processes, such as cell differentiation and future development [44-46].

DNA demethylation in the human preimplantation embryo occurs in a stepwise manner reaching a mean DNA methylation level of $25.7 \%$ in blastocyst-stage embryos at five to six days pf $[13,19]$. This is significantly lower than the median DNA methylation levels in the egg of $54.5 \%$ and sperm of $82 \%$, indicating a significant reduction from the highly specialized gametes to the totipotent embryo $[13,19]$. Generally, the oocyte hypermethylated domains maintain intermediate methylation levels in the blastocyst [47], but they respond differently to global demethylation based on their genomic properties. For example, transposable elements which are hypermethylated in oocytes are drastically demethylated in blastocysts, with the exception of SINE-VNTR-Alu (SVA) and LTR12 subfamilies, which retain high levels of residual methylation throughout the preimplantation period $[13,48]$. More so than in mouse embryos, highly methylated CGIs retain substantial levels of methylation in human embryos (median of methylation of these CGIs and gDMRs in the blastocyst is $37.5 \%$ and $39.2 \%$, respectively) [13]. The maternal genome is less demethylated in humans than in mouse embryos during preimplantation development. Consequently, the global methylation levels of the human blastocyst closely resemble those of the oocyte [47].

Demethylation of the paternal genome is much faster and more profound than that of the maternal genome in human embryos, which is more similar to the same process in the mouse, suggesting that active demethylation is conserved between the two species [38,48]. Accordingly, the residual DNA methylation levels, in either male pronuclei or the paternal genome domains from the 2-cell stage onward are always lower compared to those of the maternal genome $[19,38]$.

In addition to genome-wide demethylation events, limited de novo methylation of active repeat elements during preimplantation development in human embryos has recently been reported [19]. In particular, SINEs, LINEs, and long terminal repeats (LTRs) acquire DNA methylation at two stages: from the early male pronuclear to the midpronuclear stage and from the four-cell to the eight-cell stage on the paternal genome. The function of this de novo methylation has not been elucidated, and the majority of de novo methylated sites lose their methylation again after the next cell division. One hypothesis is that de novo methylation of active repeat elements guarantees genome stability by further repressing those elements at a stage where genome integrity is at its greatest risk $[19,38,49]$.

\subsection{Post-Implantation Embryo}

The blastocyst represents the stage at which the first cellular lineages have become apparent, comprising the trophectoderm (TE), which gives rise to the extraembryonic tissues, and the inner cell mass (ICM), which gives rise to embryonic tissues. In humans, the embryo implants into the uterine wall approximately on day seven after fertilization. By the time the blastocyst progresses to the post-implantation stage, the genomes of both embryonic and extraembryonic tissues have undergone massive tissue-specific and stagespecific DNA-remethylation (Figure 1) [50]. In the mouse, DNMT3A/B are responsible for this de novo methylation which is essential for gastrulation and proper cellular differentiation into the three germ layers: Endoderm, mesoderm, and ectoderm [51,52]. However, in mice, the regulation of DNA methylation in the extraembryonic lineages (which give rise to the placenta) is different from that in the embryonic lineages [53]. Human placental villi are composed of trophoblast, which derives from the TE, and mesenchyme, which 
originates from ICM-derived extraembryonic mesoderm [54]. As mentioned above, during post-implantation development the genome acquires de novo methylation. However, the placenta maintains a general hypomethylated epigenome compared to the embryo [55]. The placental methylome is organized into partially methylated domains (PMD) and highly methylated domains (HMD) [56]. PMDs are large domains covering about $40 \%$ of the genome with an average DNA methylation level of $45 \%$ (compared to $80 \%$ in HMDs) and overall lower transcription levels than the rest of the genome. The placenta is the only somatic tissue with such extensive PMDs, which are stable throughout gestation. Genes enriched within PMDs have low gene-body methylation levels and lower gene expression compared to those within HMD.

\section{Methylation Patterning of Imprinted Genes}

Imprinted genes occupy a small fraction of the genome and are mono-allelically expressed in a parent-of-origin-dependent manner. They fulfill important functions during the development and disruption of their mono-allelic expression results in several different imprinting syndromes, depending on the affected gene(s) [57]. Many imprinted genes are organized in clusters and each cluster is regulated by an ICR [20,58]. Canonical imprinted genes have differential methylation of the ICR that is established in the germline (gDMR) and is protected from the waves of demethylation and re-methylation during early embryonic development. In contrast, non-canonical imprinting is a DNAmethylation-independent imprinting process $[59,60]$. This mode of imprinting has recently been described in mice, but it is not yet known if it also occurs in humans and its significance also remains unclear. Non-canonical imprinting is set by H3K27me3 in the oocyte, which results in mono-allelic expression of the corresponding genes from the paternal allele in the preimplantation embryo. However, the H3K27me3 mark is lost during preimplantation development and replaced by monoallelic DNA methylation during post-implantation development specifically in the extra-embryonic lineages [60,61]. Further research is needed to understand how this form of imprinting is maintained throughout pre-implantation development, whether the mechanism is conserved in other species and the particular function of placenta-specific imprinting.

The majority of imprinted genes are epigenetically specified in the female germline. Maternal gDMRs are set during the phase of de novo DNA methylation in the growing oocyte along with the remainder of the methylome. While the rest of the genome is subject to reprogramming after fertilization, gDMRs are largely protected and maintain their methylation from the zygote to post-implantation stage [38,62]. In mice, DNA methylation of the methylated allele of ICRs is maintained by ZFP57, a Kruüppel-associated box (KRAB)containing zinc finger protein. ZFP57 recognizes and binds to the methylated allele of all murine and most human gDMRs and recruits its cofactor KAP1 (also known as TRIM28). The ZFP57/KAP1 complex then recruits other epigenetic modifiers, including SETDB1 and DNMT1, to the gDMRs to protect the methylated allele from demethylation $[63,64]$. In mice, ZFP57 is continually expressed from the oocyte to the early embryo, and it has been shown that oocyte expression of ZFP57 is required for the proper maintenance of gDMRs [63]. In humans, ZFP57 is expressed only in the early embryo with zygotic genome activation $[45,65]$. It is unclear if this difference in expression has any effect on function, but loss of function mutations of human ZFP57 disrupt the maintenance of imprinting resulting in MLID [66]. Even so, in these patients, not all imprinted genes are affected suggesting that other complementary factors may play a role. Recent studies identified other zinc finger proteins, ZFP445 and ZNF202, that bind the majority of ICRs and are expressed in oocytes; ZFP445, in particular, appears to be more important for imprinting maintenance in human embryos. In a recent study, for the first time a homozygous ZFP445 variant was found. This pathogenic variant caused Temple syndrome and MLID in the patient $[65,67,68]$.

During the remethylation phase in the post-implantation embryo, the unmethylated allele of canonical imprinted genes is protected against de novo methylation, passing 
lifelong memory of parental origin into the next generation (Figure 1) $[69,70]$. In humans, some gDMRs are maintained exclusively in the placenta. This phenomenon is called placenta-specific imprinting and has not yet been observed in the mouse [47,54,71-74]. Most placenta-specific imprinted genes are transient and retain methylation of maternal origin set in the oocyte [54,71]. Placenta-specific imprinted genes show mono-allelic methylation on the maternal allele in placental villi, cytotrophoblasts, trophoblast, and mesenchyme mostly become unmethylated in somatic tissues [54,71]. The incomplete demethylation of the maternal allele during preimplantation development or incomplete de novo methylation of the paternal allele post-implantation are proposed as mechanisms of placenta-specific imprinting [47].

\section{Global Loss of Imprinting Results in Hydatidiform Molar Pregnancies}

The two waves of DNA methylation reprogramming in the germline and the early embryo are important for normal development. In particular, the establishment and maintenance of imprints have been shown to be crucial for the maintenance of a healthy pregnancy. Therefore, the loss of imprinting results in a variety of developmental abnormalities [21,75]. The most severe form is the hydatidiform mole (HM), which is a gestational abnormality characterized by trophoblast overgrowth and the absence of embryo development [76]. In most cases, HM pregnancies occur sporadically and are the result of an androgenetic embryo that has two paternal genome copies and is lacking the maternal copy. The lack of the maternal copy consequently means that all maternal imprints are missing, while the paternal imprints are fully methylated, which is thought to be the main factor driving the HM phenotype. In mice, androgenetic pregnancies lacking maternal imprints show similarities to the HM phenotype in that they are characterized by trophoblast overgrowth and abnormal development of the embryo proper $[77,78]$. The lack of imprinting results in the imbalance of imprinted gene expression. In a recent study using bipaternal mice, this imbalance of expression was corrected at seven imprinted loci, which resulted in the birth of live pups, highlighting the importance of mono-allelic expression of imprinted genes for normal pregnancies [79].

In rare cases, $\mathrm{HM}$ are recurrent, and in most such instances, this coincides with a biparental genome. These are termed biparental complete hydatidiform mole (BiCHM). The majority of BiCHM pregnancies have been associated with mutations in the maternal-effect genes NLRP7 ( 75\%) and KHDC3L ( 5-10\%) [25]. Recently, a patient with a PADI6 mutation was identified [80]. In contrast to androgenetic HMs, BiCHM has a maternal copy of the genome. Their phenotype is associated with widespread loss of methylation at (almost) all maternal gDMRs in patients with disease variants in NLRP7 and KHDC3L [22,81-84]. Given that only the maternal and not paternal gDMRs appear to be affected, it was suggested that the loss of methylation originates in the oocyte. Indeed, a recent study assessing DNA methylation in oocytes of a patient with a KHDC3L mutation showed that global DNA methylation establishment in the oocyte was impaired, including but not limited to the maternal gDMRs [24]. While the majority of the methylome recovered post-implantation, as assessed in the molar tissue, thus suggesting normal de novo methylation in the embryo, the maternal gDMRs were not rescued [24]. However, this has only been shown for a single patient with a KHDC3L mutation and does not exclude the possibility that in other patients $\mathrm{BiCHM}$ pregnancies may be a result of failed gDMR maintenance or a combination of defects in the oocyte and preimplantation embryo. This is supported by patients in which NLRP7 mutations have been associated with MLID in which paternal gDMRs were also affected [28].

\section{Molar Pregnancies Indicate a Role for the Subcortical Maternal Complex in Ensuring Imprinting}

Although the evidence described above implicates NLRP7 and KHDC3L in the establishment of maternal gDMRs in the oocyte, the mechanism of how this may occur remains unexplained. NLRP7 and KHDC3L are both parts of the same oocyte multi-protein complex, the subcortical maternal complex (SCMC) [85]. The SCMC was first described in mice 
and regulates several essential cellular processes during the egg-to-embryo transition, such as spindle assembly, chromosome alignment, and symmetric cell division in cleavage-stage embryos [86,87]. The SCMC has since also been detected in other mammalian species, including humans $[85,88]$. In humans, seven genes have, so far, been described to encode proteins of the SCMC: NLRP5 (MATER), OOEP (FLOPED), TLE6, NLRP2, NLRP7, KHDC3L (C6ORF221), and PADI6 [85,89-91].

The SCMC is localized in the subcortical region of the cytoplasm just below the cell membrane or cortex of the oocyte and persists throughout preimplantation development until the blastocyst stage, where it is excluded from regions with cell-cell contact. The cytoplasmic localization of the SCMC makes a potential role in imprinting regulation all the more intriguing. As discussed above, mutations in NLRP7, KHDC $3 L$, and, potentially, PADI6 are associated with BiCHM pregnancies. Other genes, including NLRP5, NLRP2, NLRP7, PADI6, and OOEP, have been associated with MLID and miscarriages $[22,27,28,92]$. MLID is thought to occur from failure of gDMR maintenance in preimplantation embryos because, in contrast to BiCHM, only a variable subset of gDMRs is affected in MLID. The cause of the high frequency of miscarriages in some women with SCMC mutations is unknown $[22,27,28]$. One possibility is that the number of imprinted genes affected varies between offspring, and only milder cases develop to term. Another gene frequently mutated in MLID is ZFP57 [66] which, together with DNMT1 and TRIM28, encodes part of the DNA methylation maintenance machinery of gDMRs during preimplantation development [93]. How the SCMC members impact the maintenance machinery remains to be resolved. One possibility is that the SCMC functions as a regulator of cellular organization and through that can regulate the localization of proteins involved in DNA methylation, such as DNMTs. Indeed, knockout of Nlrp2 in mice disrupts the subcellular localization of DNMT1, but not DNMT3A [94]. Immunofluorescence showed that DNMT1, which was enriched in the cortex together with other SCMC proteins in control oocytes and preimplantation embryos, had a more diffuse cytoplasmic rather than cortical localization in maternal knockout zygotes [94]. This would suggest an involvement of NLRP2 in DNA methylation maintenance, which fits with the association of NLRP2 with MLID in humans [28,92]. Mid-gestation embryos and neonates from Nlrp2-deficient oocytes did indeed show small alterations in methylation at imprinted gDMRs [94]. Nlrp2 is so far the only mouse gene in which a link between the SCMC and imprinting regulation has been made. It will be interesting to assess the role of Nlrp2 and other SCMC genes in imprinting in mice more comprehensively, to improve our understanding of conditions such as BiCHM and MLID.

Studying SCMC function in humans is challenging, as the genes are exclusively expressed in oocytes and human material is extremely rare, even more so from patients with pathogenic variants. Furthermore, not all SCMC members are conserved in mammals, as some, such as the NLRPs, belong to rapidly evolving gene families [95]. For example, NLRP7, the major gene involved in BiCHM, is not found in the mouse, making the use of animal models difficult. Mouse knockout studies have shown that the SCMC proteins are tightly regulated. Except for Khdc3 (Filia), the mouse orthologue of KHDC3L, the knockout of any one of the SCMC genes destabilizes the entire complex and results in dispersing protein localization of the other members $[86,96,97]$. These knockout studies also showed that ablation of one of the SCMC proteins usually results in embryo arrest at the zygote or early cleavage stages $[29,86,98]$. This very early embryo arrest is not linked to imprinting, as oocyte-specific deletion of Dnmt3a or Dnmt3l in mice, which results in complete loss of maternal imprinting, does not cause any phenotype until later in development $[35,99]$.

The discrepancy between human and mouse studies may partly be caused by under ascertainment of human cases. Mosaicism in patients may affect the diagnosis of MLID [21]. Furthermore, pathogenic genetic variants that are compatible with life in the case of MLID or with pregnancy in the case of BiCHM are more likely to be detected than those that cause early preimplantation embryo arrest. There is growing evidence supporting that mutations in genes encoding SCMC members may be associated with early embryo arrest 
independent of imprinting disorders [100-104]. It has been proposed that there might be a causal link between the SCMC, DNA methylation, and genome integrity, as imprinting aberrations have been associated with aneuploidies in the embryos of patients with SCMC mutations $[21,22,28,75]$. A role for the SCMC in ploidy is also supported by a mouse study, in which maternal ablation of Khdc3 caused abnormal spindle assembly, chromosome misalignment, and spindle assembly checkpoint inactivation during the early embryo cleavage stages, resulting in increased aneuploidy rates [96]. A combination of imprinting defects and aneuploidy may therefore be at the core of explaining miscarriages often observed in patients with SCMC mutations.

\section{Pathogenic Variants Identified within Human SCMC Genes}

Numerous families and singletons with early embryonic lethality, MLID, and BiCHM have been studied to find the causative genes for these conditions. DNA from probands and family members have been subjected to whole-genome or whole-exome sequencing, and variants have been classified and annotated. Rare homozygous and compound heterozygous variants have been identified in NLRP2, NLRP5, NLRP7, KHDC3L, TLE6, PADI, $O O E P, U H R F 1$, and ZAR1. In most cases, the segregation in familial presentations was confirmed. Reported variants in genes that encode SCMC proteins and associated clinical features have been compiled in the Table 1. 
Table 1. Summary of familial and singleton variants within SCMC genes causing early embryonic lethality, MLID, and BiCHM.

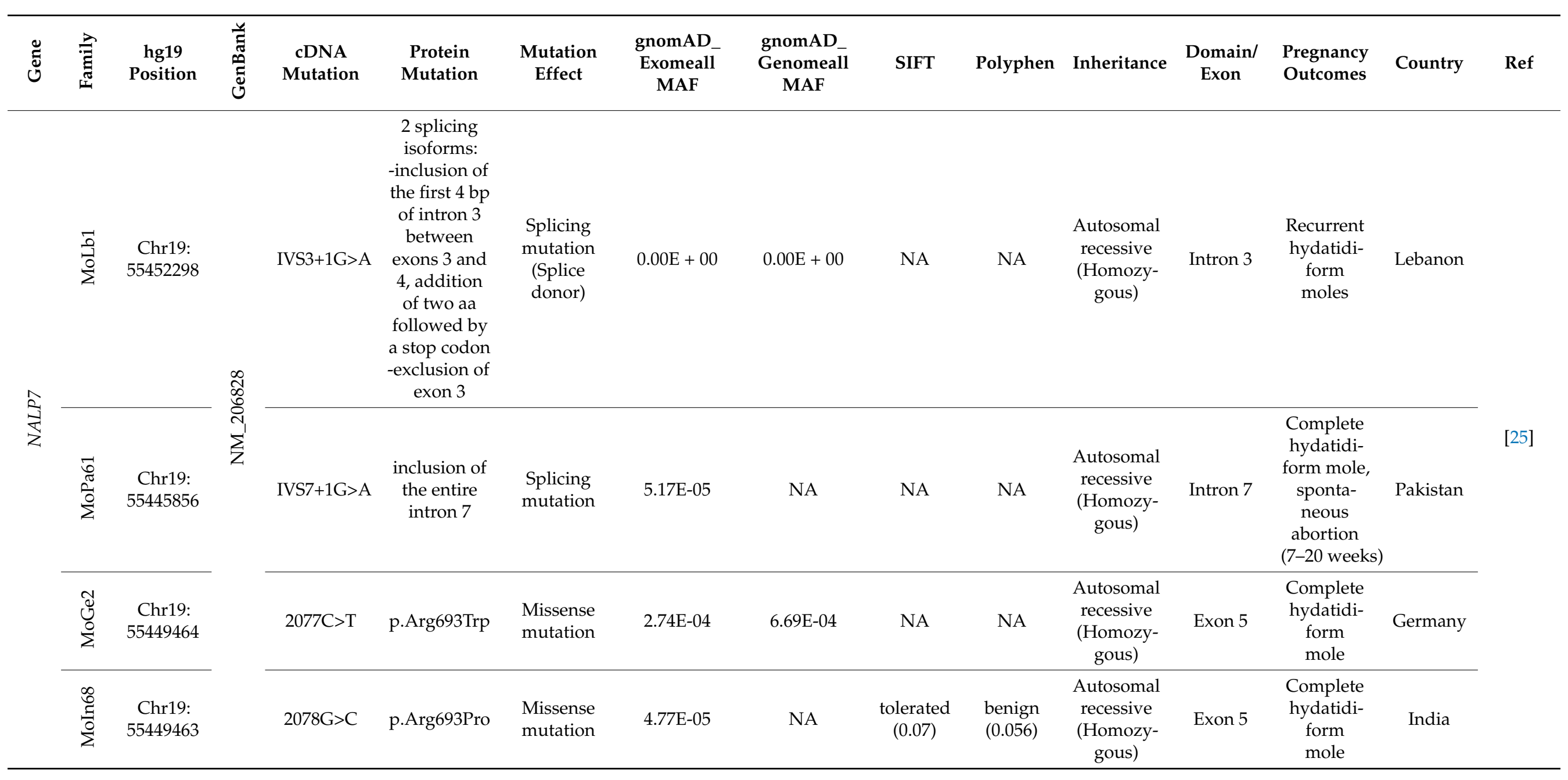


Table 1. Cont.

\begin{tabular}{|c|c|c|c|c|c|c|c|c|c|c|c|c|c|c|c|}
\hline ษั๊ & 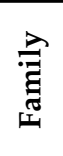 & $\begin{array}{c}\text { hg19 } \\
\text { Position }\end{array}$ & 光 & $\begin{array}{l}\text { cDNA } \\
\text { Mutation }\end{array}$ & $\begin{array}{l}\text { Protein } \\
\text { Mutation }\end{array}$ & $\begin{array}{c}\text { Mutation } \\
\text { Effect }\end{array}$ & $\begin{array}{l}\text { gnomAD_- } \\
\text { Exomeall } \\
\text { MAF }\end{array}$ & $\begin{array}{l}\text { gnomAD_ } \\
\text { Genomeall } \\
\text { MAF }\end{array}$ & SIFT & Polyphen & Inheritance & $\begin{array}{l}\text { Domain/ } \\
\text { Exon }\end{array}$ & $\begin{array}{l}\text { Pregnancy } \\
\text { Outcomes }\end{array}$ & Country & Ref \\
\hline & 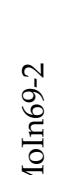 & $\begin{array}{c}\text { Chr19: } \\
55441939\end{array}$ & & c. $2738 \mathrm{~A}>\mathrm{G}$ & p.Asn913Ser & $\begin{array}{l}\text { Missense } \\
\text { mutation }\end{array}$ & $1.35 \mathrm{E}-04$ & 7.33E-04 & $\begin{array}{l}\text { deleterious } \\
\text { (0) }\end{array}$ & $\begin{array}{c}\text { probably_ } \\
\text { damag- } \\
\text { ing } \\
(0.991)\end{array}$ & $\begin{array}{l}\text { Autosomal } \\
\text { recessive } \\
\text { (Com- } \\
\text { pound }\end{array}$ & Exon 5 & $\begin{array}{l}\text { Complete } \\
\text { hydatidi- } \\
\text { form mole } \\
\text { and }\end{array}$ & India & \\
\hline \multirow{7}{*}{$\begin{array}{l}\hat{\Sigma} \\
\Sigma \\
\Sigma\end{array}$} & $\begin{array}{l}0 \\
\stackrel{2}{=}\end{array}$ & $\begin{array}{c}\text { Chr19: } \\
55447768\end{array}$ & \multirow{4}{*}{ 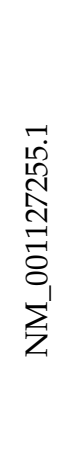 } & c. $2161 \mathrm{C}>\mathrm{T}$ & p.Arg721Trp & \multirow{2}{*}{$\begin{array}{l}\text { Missense } \\
\text { mutations }\end{array}$} & 5.97E-05 & NA & NA & NA & \multirow{2}{*}{$\begin{array}{l}\text { Compound } \\
\text { Heterozy- } \\
\text { gous }\end{array}$} & Exon 7 & \multirow{2}{*}{$\begin{array}{l}\text { BWS- } \\
\text { MLID }\end{array}$} & \multirow{2}{*}{ Germany } & \multirow{4}{*}{ [28] } \\
\hline & 馬 & $\begin{array}{c}\text { Chr19: } \\
55445006\end{array}$ & & c. $2573 \mathrm{~T}>\mathrm{C}$ & p. Ile858Thr & & 7.16E-05 & 6.37E-05 & $\begin{array}{l}\text { deleterious } \\
\text { (0) }\end{array}$ & $\begin{array}{l}\text { benign } \\
(0.351)\end{array}$ & & Exon 8 & & & \\
\hline & \multirow[t]{2}{*}{ 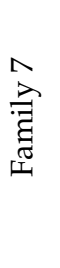 } & $\begin{array}{c}\text { Chr19: } \\
55451438\end{array}$ & & c.749T>G & p.Phe250Cys & \multirow[t]{2}{*}{$\begin{array}{l}\text { Missense } \\
\text { mutations }\end{array}$} & 4.57E-04 & $4.14 \mathrm{E}-04$ & $\begin{array}{l}\text { deleterious } \\
\text { (0) }\end{array}$ & $\begin{array}{c}\text { possibly_ } \\
\text { damag- } \\
\text { ing } \\
(0.88)\end{array}$ & $\begin{array}{l}\text { Compound } \\
\text { Heterozy- } \\
\text { gous } \\
\text { (Mother) }\end{array}$ & $\begin{array}{l}\text { NACHT } \\
\text { domain }\end{array}$ & \multirow{2}{*}{$\begin{array}{l}\text { BWS and } \\
\text { TNDM }\end{array}$} & & \\
\hline & & $\begin{array}{c}\text { Chr19: } \\
55451083\end{array}$ & & $\begin{array}{c}\text { c. } \\
1104 \mathrm{~T}>\mathrm{G}\end{array}$ & p.Ile368Met & & 4.84E-04 & $5.49 \mathrm{E}-04$ & NA & NA & $\begin{array}{l}\text { Heterozygous } \\
\text { in Proband }\end{array}$ & Exon 4 & & & \\
\hline & \multirow{3}{*}{ 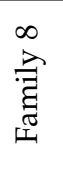 } & \multirow{3}{*}{$\begin{array}{c}\text { Chr19: } \\
55447773\end{array}$} & \multirow{3}{*}{ 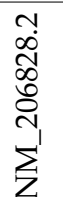 } & \multirow{3}{*}{ c. $2156 \mathrm{C}>\mathrm{T}$} & \multirow{3}{*}{ p.Ala719Val } & \multirow{3}{*}{$\begin{array}{l}\text { Missense } \\
\text { mutation }\end{array}$} & \multirow{3}{*}{$1.05 \mathrm{E}-03$} & \multirow{3}{*}{$1.05 \mathrm{E}-03$} & \multirow{3}{*}{$\begin{array}{l}\text { deleterious } \\
(0.01)\end{array}$} & \multirow{3}{*}{$\begin{array}{c}\text { probably_ } \\
\text { damag- } \\
\text { ing } \\
(0.963)\end{array}$} & \multirow{3}{*}{$\begin{array}{l}\text { Heterozygous } \\
\text { (Mother } \\
\text { and } \\
\text { Proband) }\end{array}$} & \multirow{3}{*}{ Exon 6} & \multirow{3}{*}{ SRS } & UK & [28] \\
\hline & & & & & & & & & & & & & & China & [91] \\
\hline & & & & & & & & & & & & & & Italy & [105] \\
\hline
\end{tabular}


Table 1. Cont.

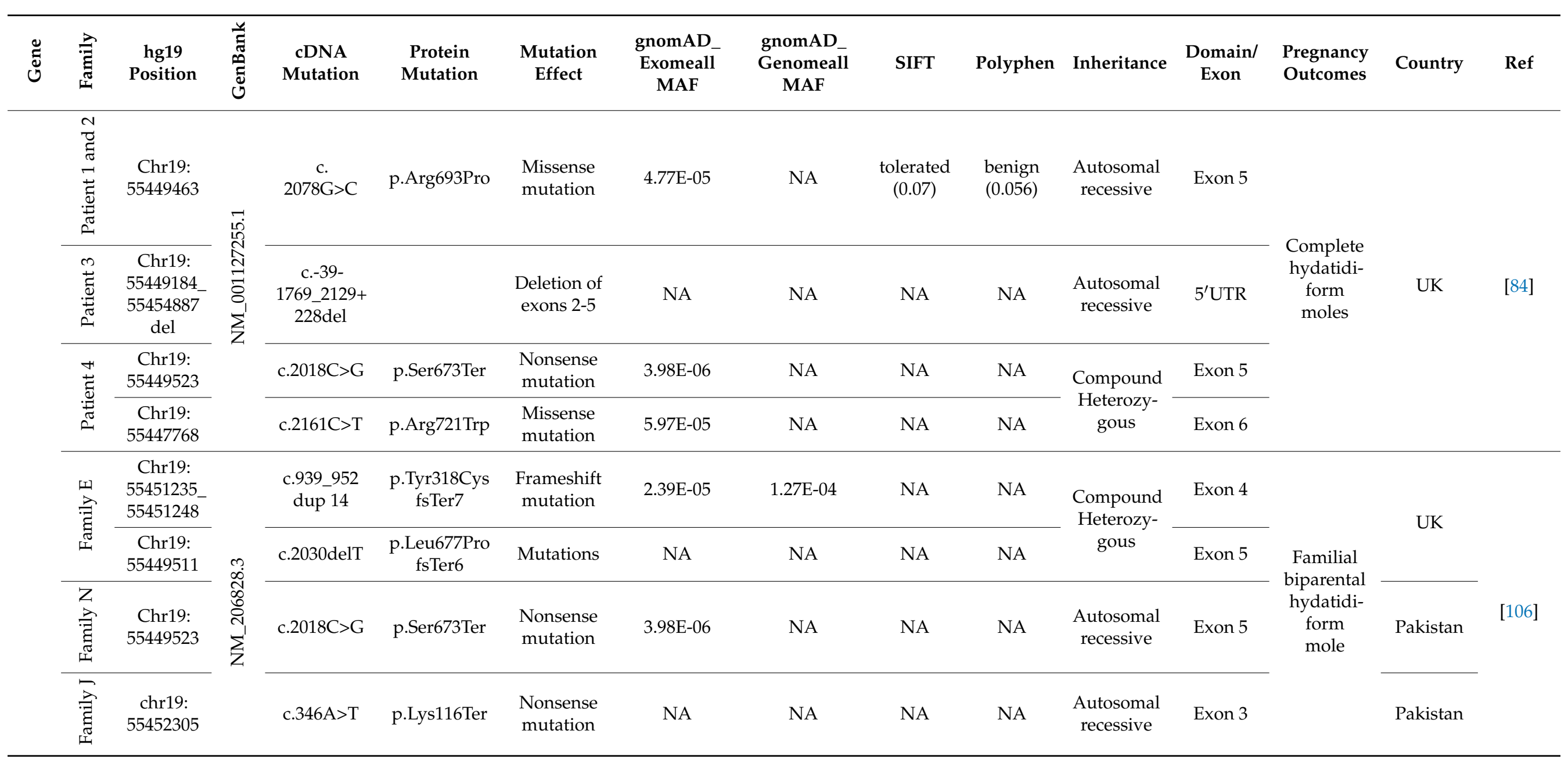


Table 1. Cont.

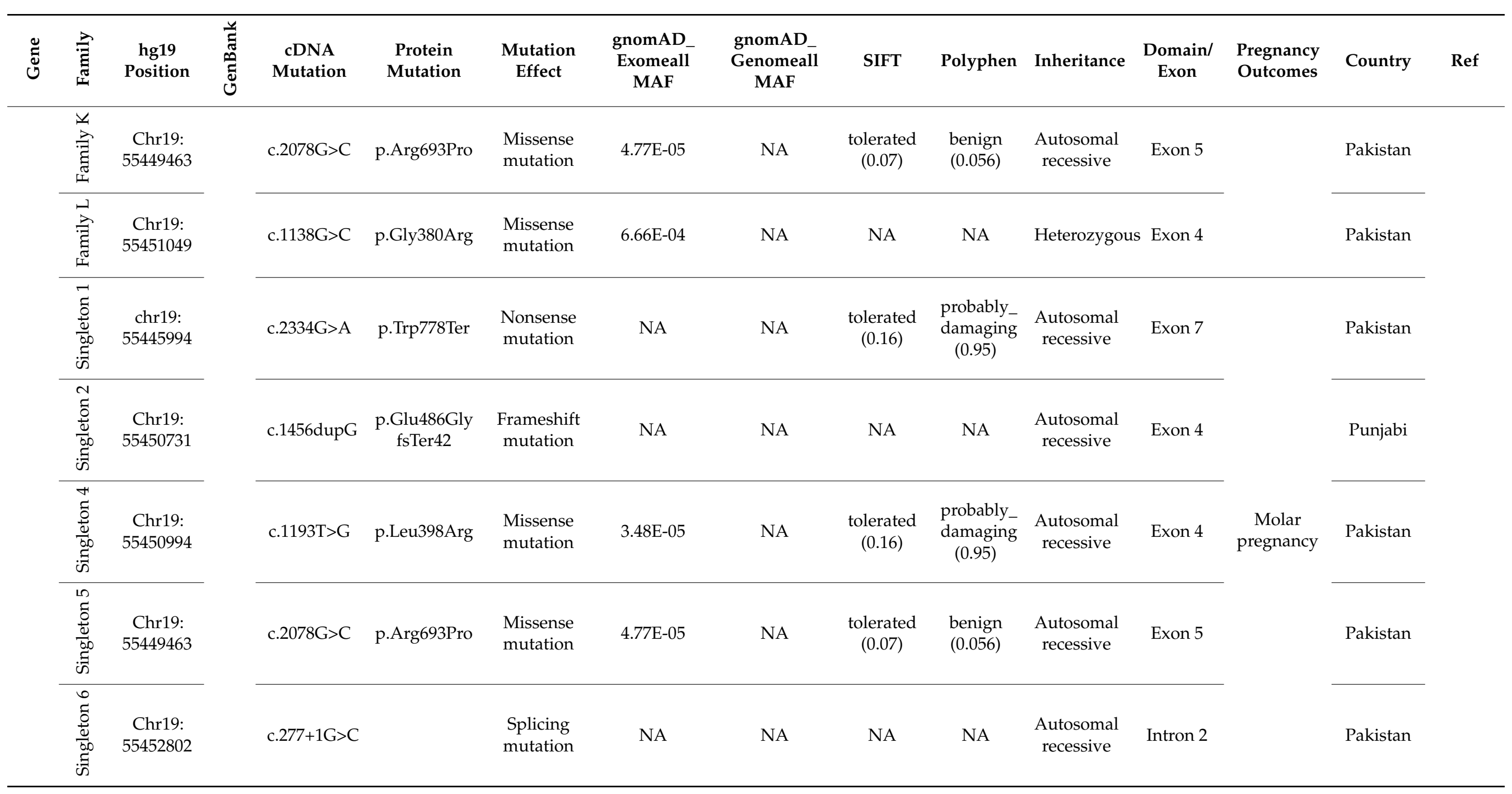


Table 1. Cont.

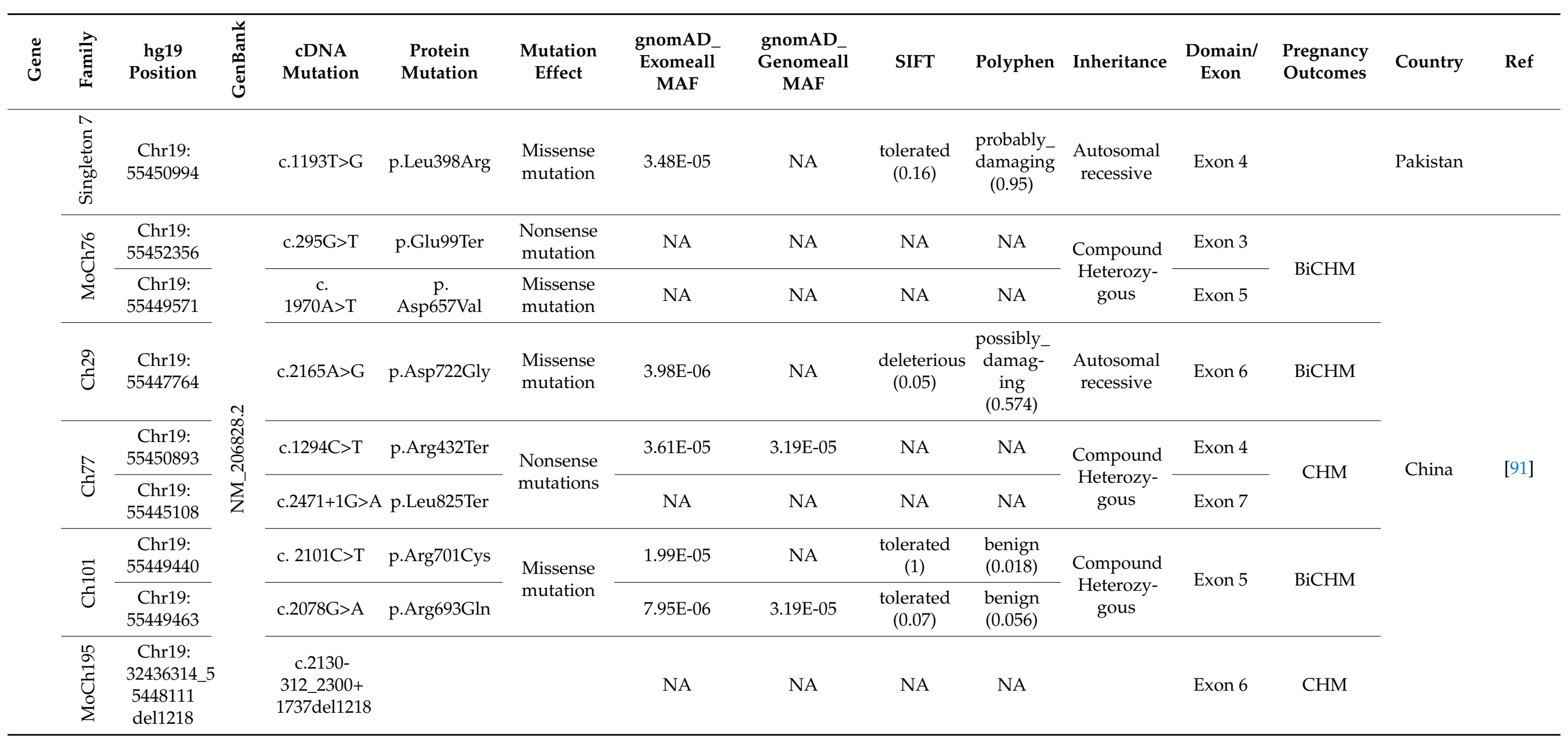


Table 1. Cont.

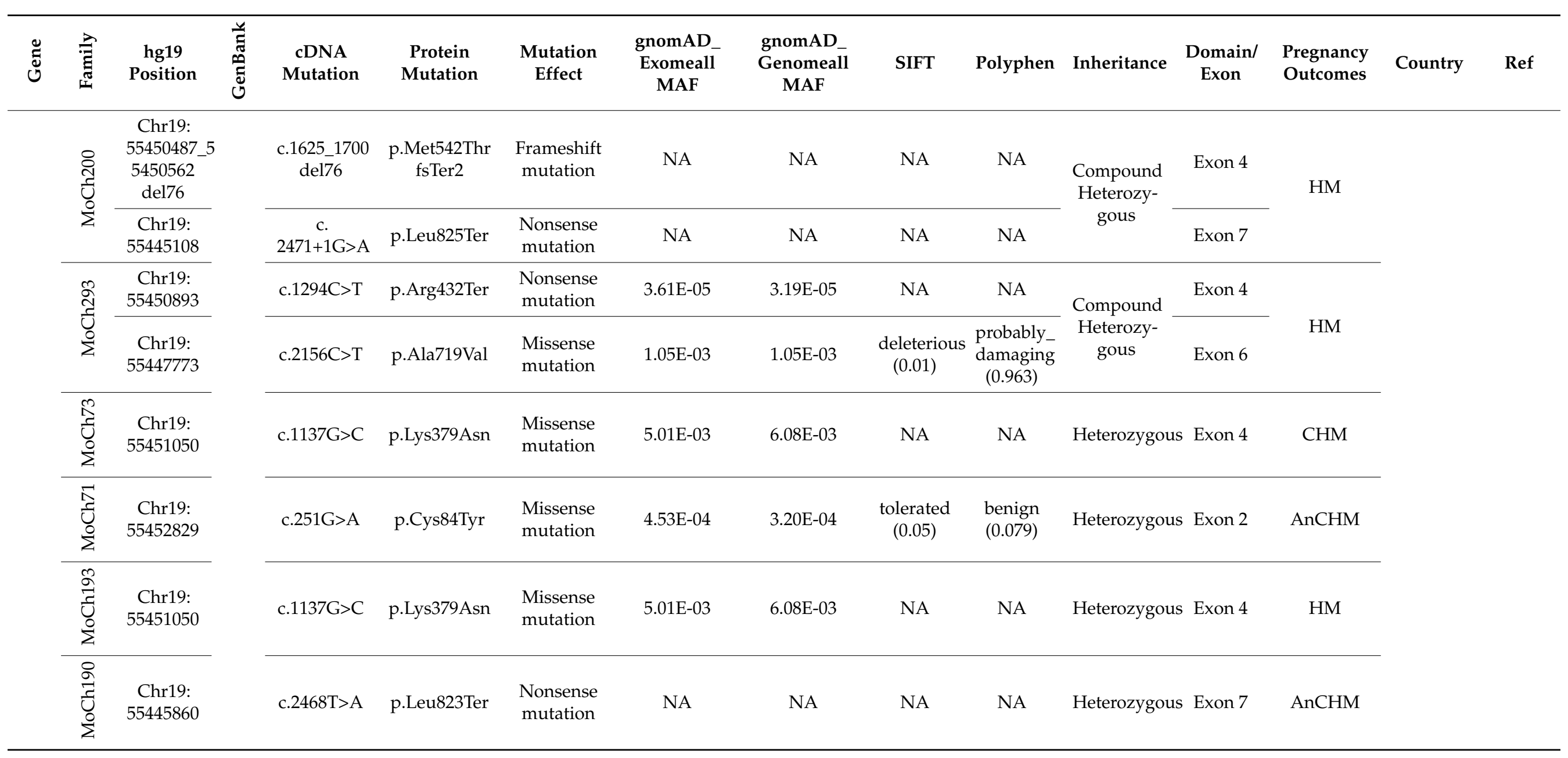


Table 1. Cont.

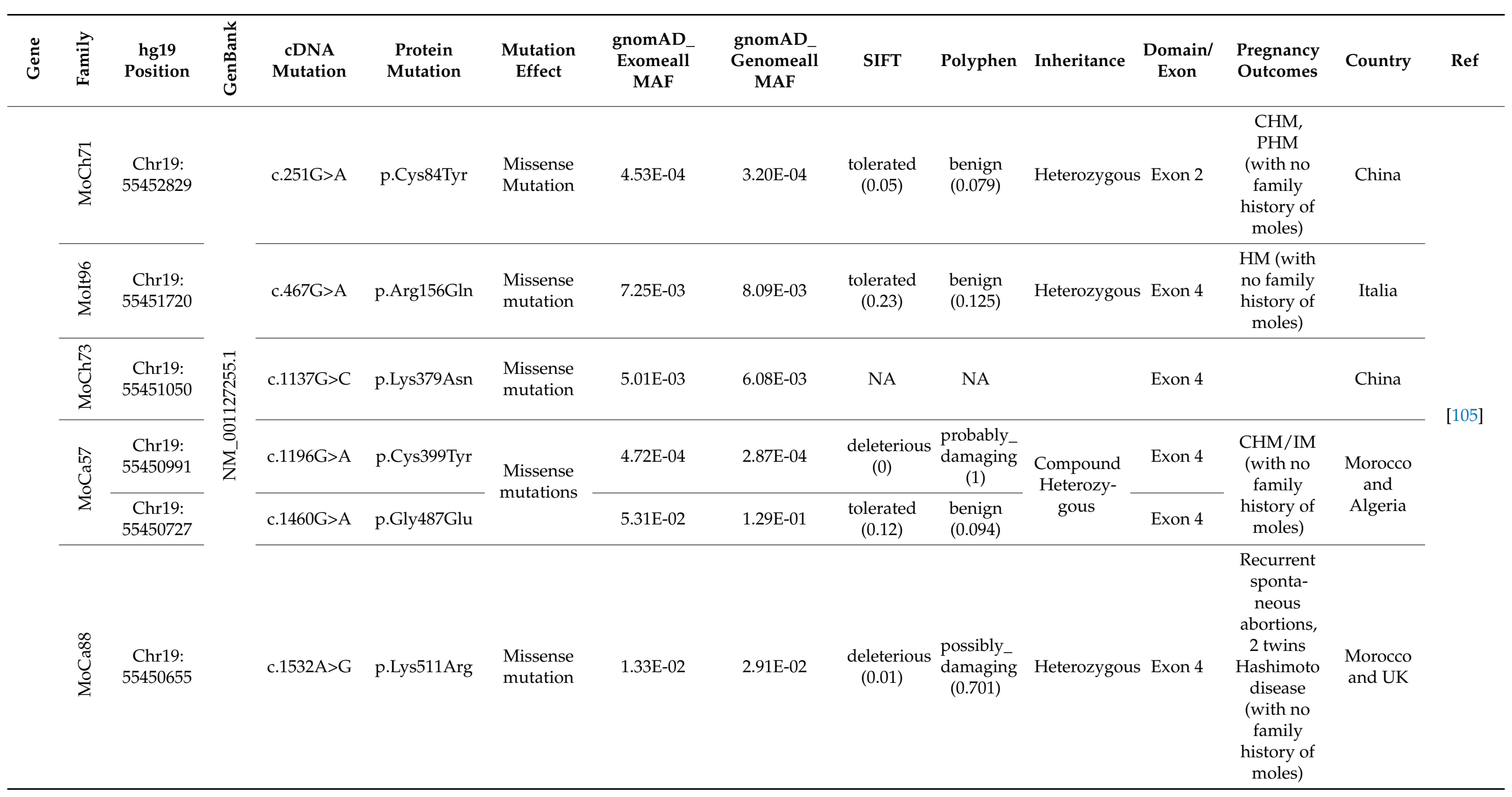


Table 1. Cont.

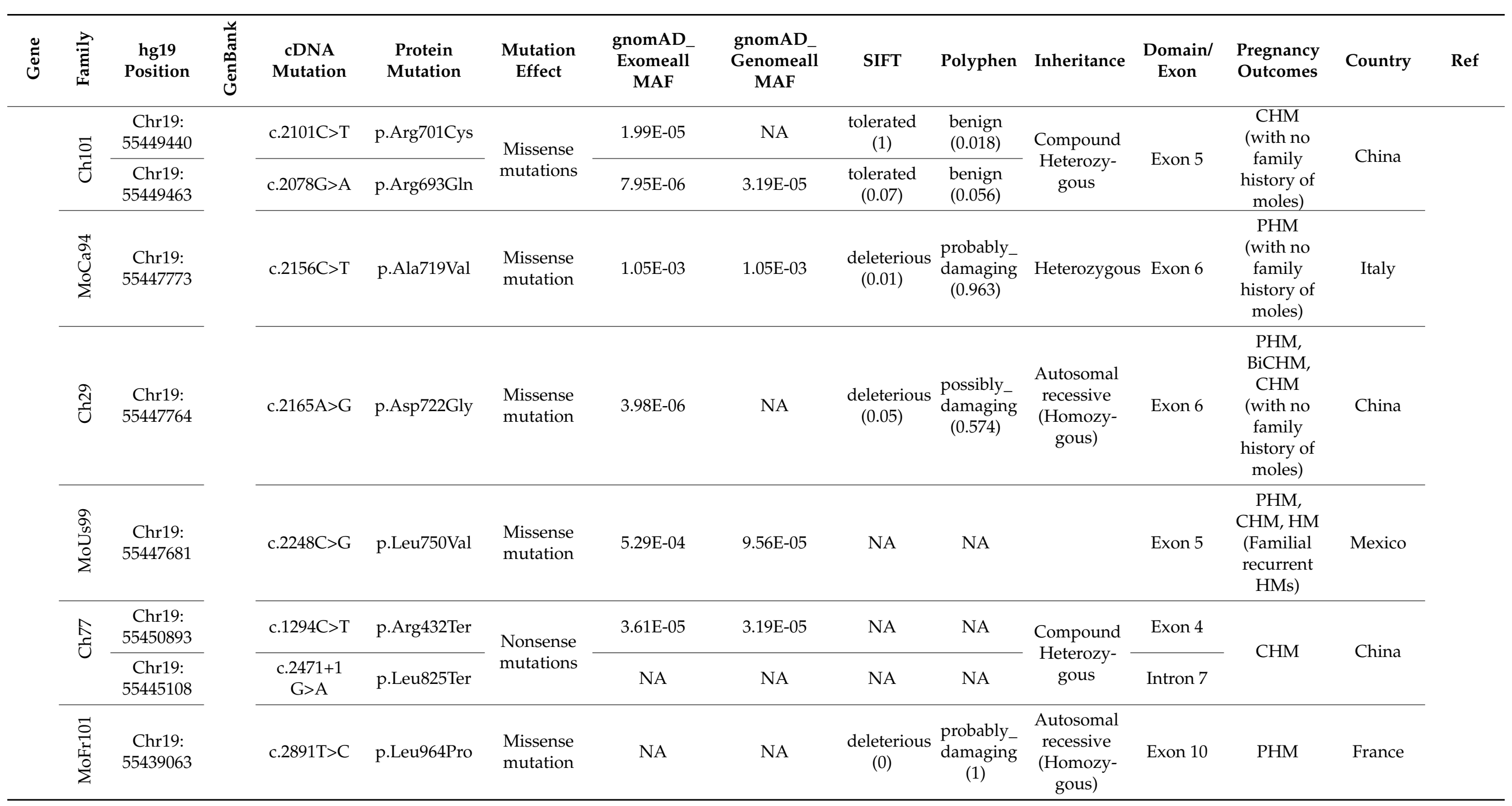


Table 1. Cont

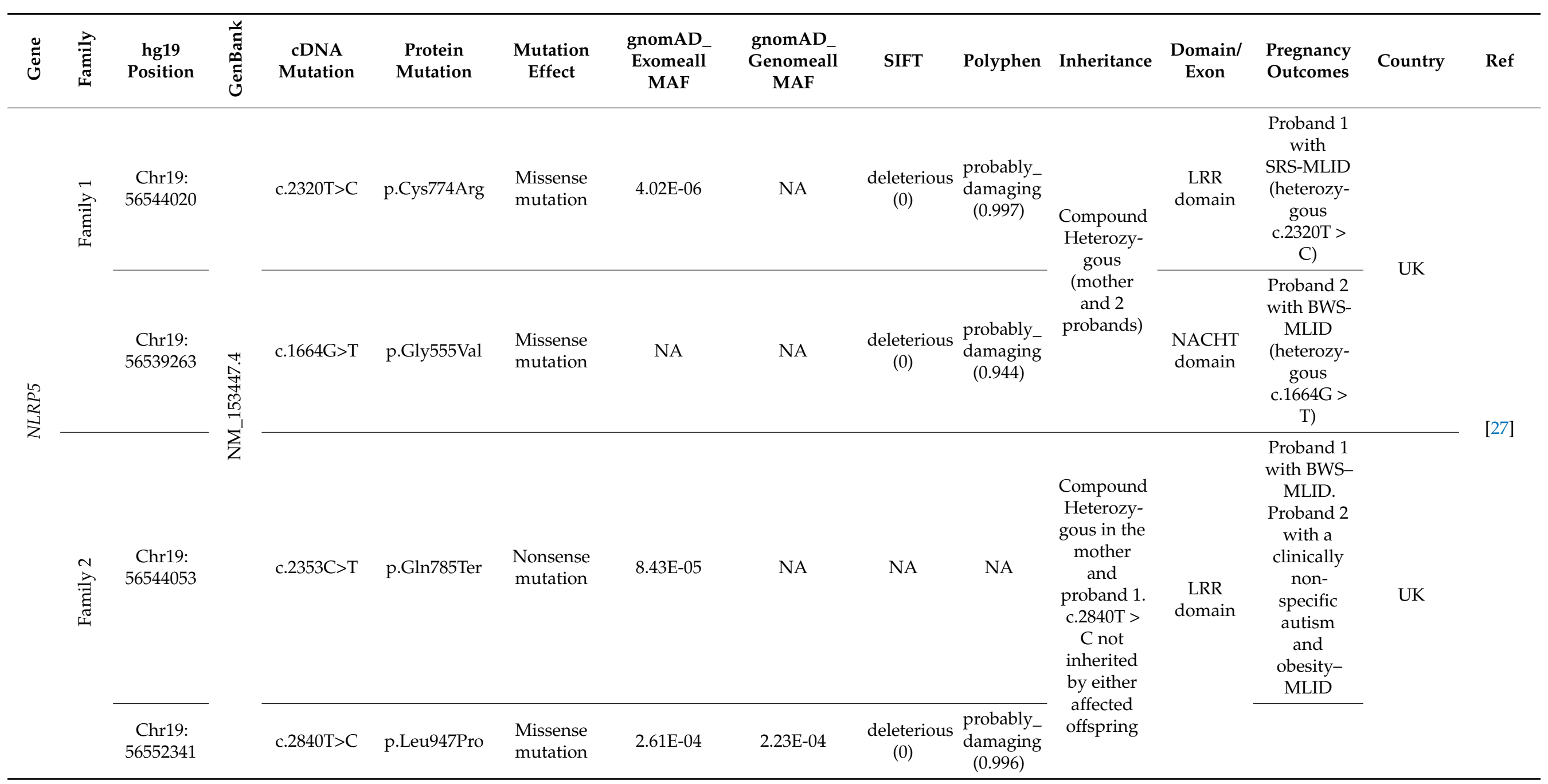


Table 1. Cont.

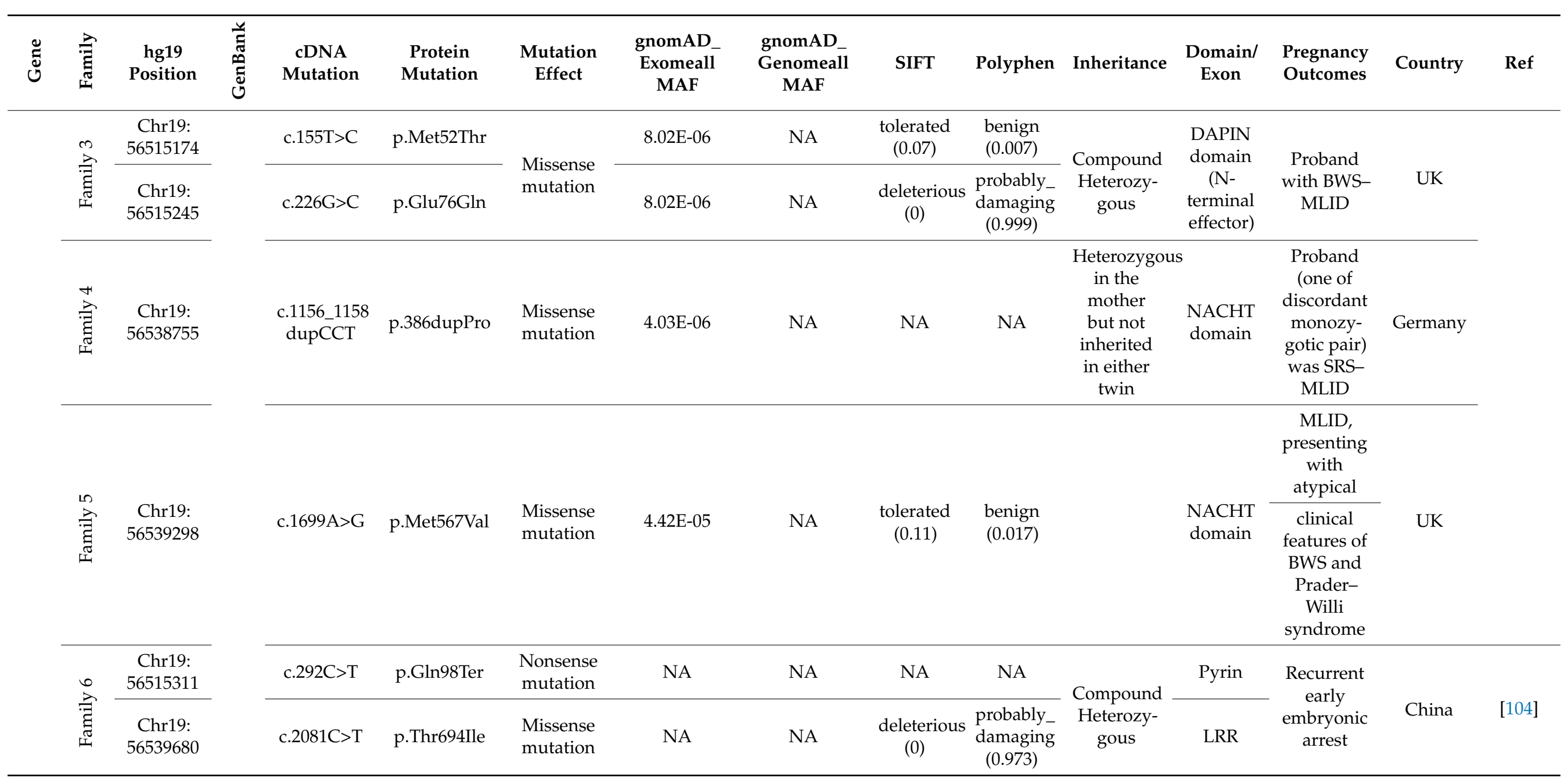


Table 1. Cont.

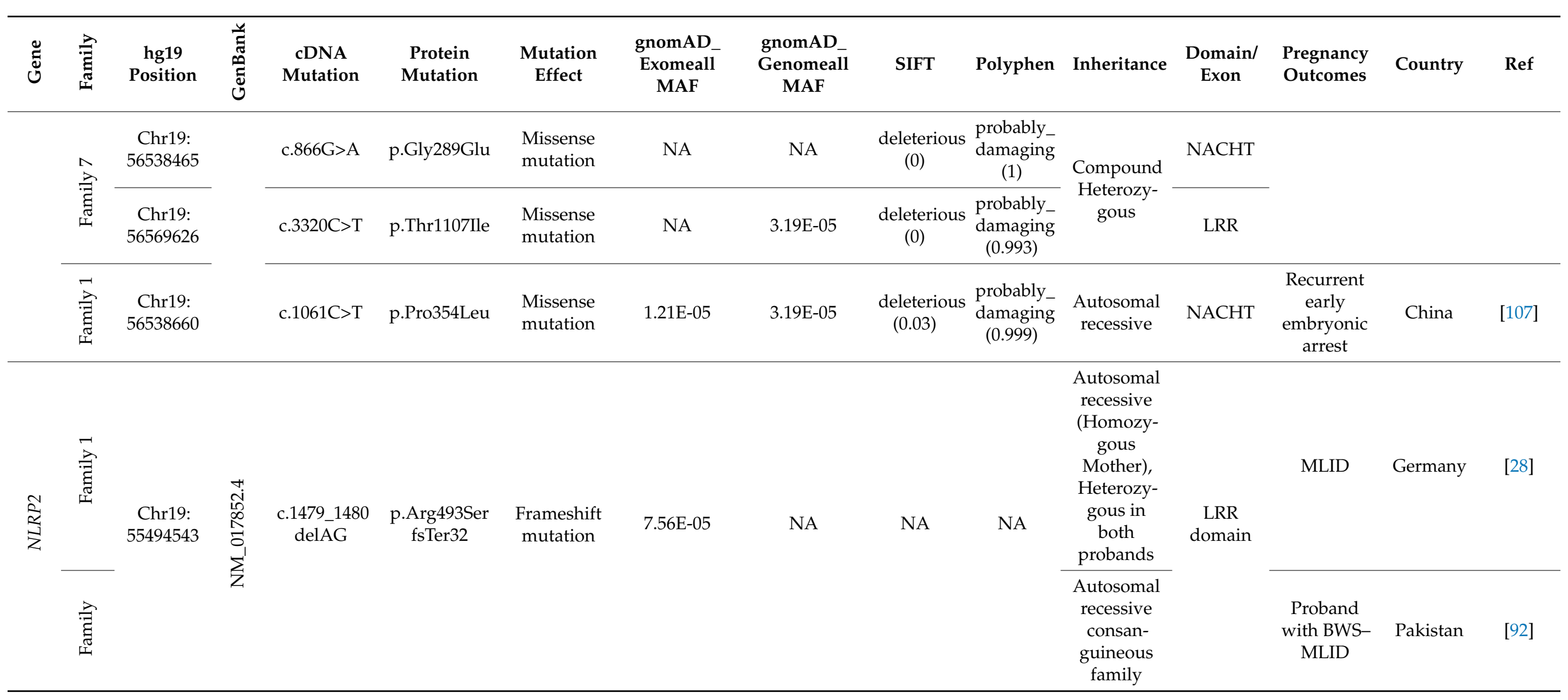


Table 1. Cont

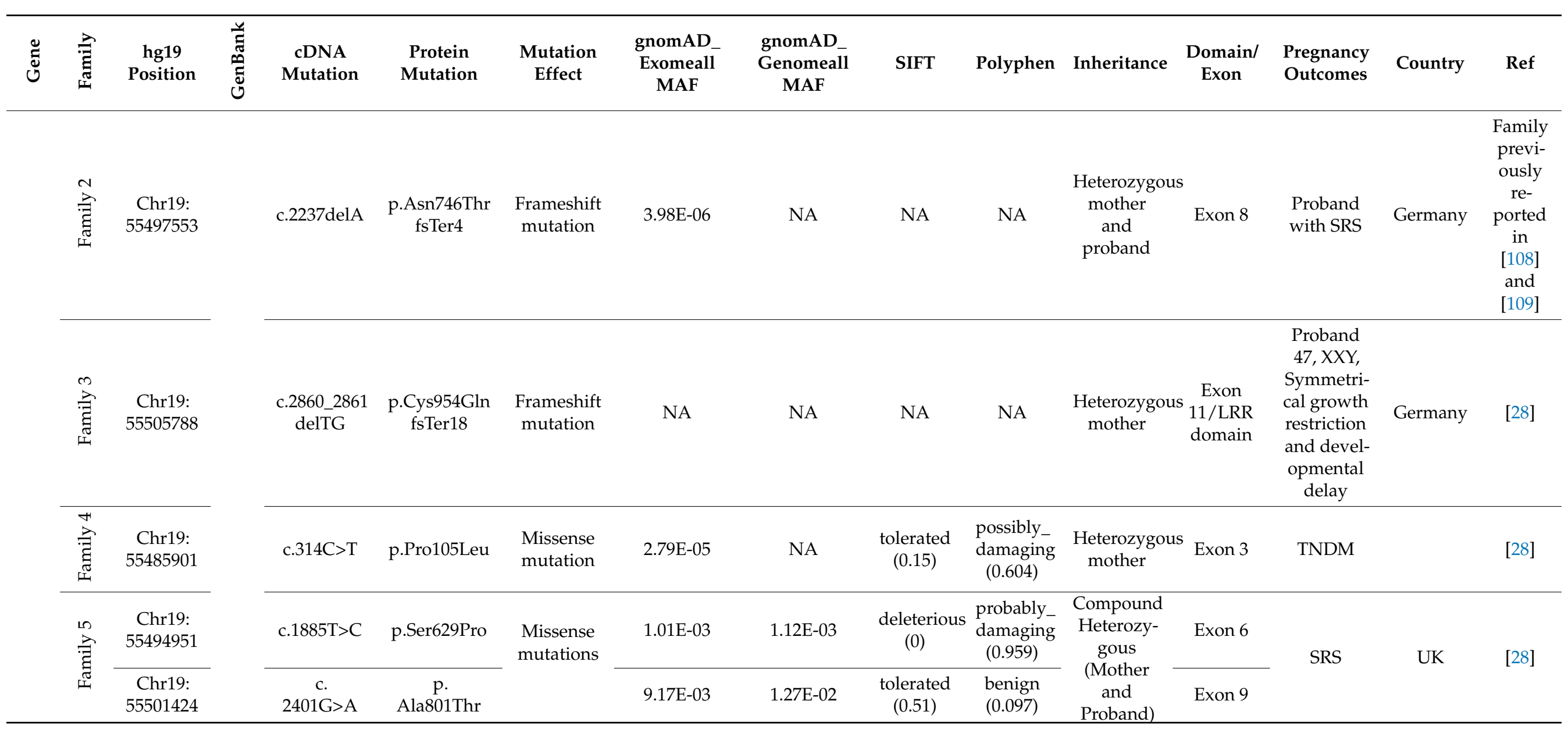


Table 1. Cont.

\begin{tabular}{|c|c|c|c|c|c|c|c|c|c|c|c|c|c|c|c|}
\hline \multirow[t]{8}{*}{$\underset{D}{\Xi}$} & 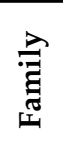 & $\begin{array}{c}\text { hg19 } \\
\text { Position }\end{array}$ & 光 & $\begin{array}{l}\text { cDNA } \\
\text { Mutation }\end{array}$ & $\begin{array}{l}\text { Protein } \\
\text { Mutation }\end{array}$ & $\begin{array}{c}\text { Mutation } \\
\text { Effect }\end{array}$ & $\begin{array}{c}\text { gnomAD_- } \\
\text { Exomeall } \\
\text { MAF }\end{array}$ & $\begin{array}{c}\text { gnomAD_ } \\
\text { Genomeall } \\
\text { MAF }\end{array}$ & SIFT & Polyphen & Inheritance & $\begin{array}{l}\text { Domain/ } \\
\text { Exon }\end{array}$ & $\begin{array}{l}\text { Pregnancy } \\
\text { Outcomes }\end{array}$ & Country & Ref \\
\hline & \multirow{2}{*}{ 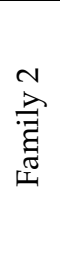 } & $\begin{array}{c}\text { Chr19: } \\
55493839\end{array}$ & \multirow{7}{*}{ 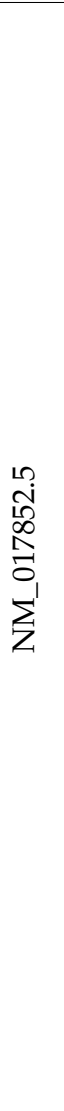 } & c.773T $>C$ & p.Phe258Ser & $\begin{array}{l}\text { Missense } \\
\text { mutation }\end{array}$ & $3.98 \mathrm{E}-06$ & NA & $\begin{array}{l}\text { deleterious } \\
\text { (0) }\end{array}$ & $\begin{array}{l}\text { probably_ } \\
\text { damag- } \\
\text { ing } \\
(0.993)\end{array}$ & \multirow{2}{*}{$\begin{array}{l}\text { Compound } \\
\text { Heterozy- } \\
\text { gous }\end{array}$} & NACHT & \multirow{7}{*}{ MLID } & \multirow{7}{*}{ China } & \multirow{7}{*}[104]{} \\
\hline & & $\begin{array}{c}\text { Chr19: } \\
55497571\end{array}$ & & c. $2254 \mathrm{C}>\mathrm{T}$ & p.Arg752Ter & $\begin{array}{l}\text { Nonsense } \\
\text { mutation }\end{array}$ & $3.98 \mathrm{E}-06$ & NA & NA & NA & & Exon 9 & & & \\
\hline & 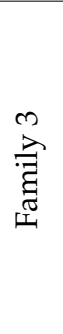 & $\begin{array}{c}\text { Chr19: } \\
55493591\end{array}$ & & c. $525 \mathrm{G}>\mathrm{C}$ & p.Trp175Cys & $\begin{array}{l}\text { Missense } \\
\text { mutation }\end{array}$ & NA & NA & $\begin{array}{c}\text { tolerated } \\
(0.06)\end{array}$ & $\begin{array}{l}\text { probably_ } \\
\text { damag- } \\
\text { ing } \\
(0.979)\end{array}$ & $\begin{array}{c}\text { Compound } \\
\text { Heterozy- } \\
\text { gous }\end{array}$ & Exon 6 & & & \\
\hline & \multirow[t]{2}{*}{ 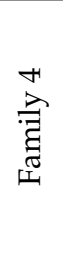 } & $\begin{array}{c}\text { Chr19: } \\
55493728\end{array}$ & & c. $662 \mathrm{C}>\mathrm{T}$ & p.Thr221Met & $\begin{array}{l}\text { Missense } \\
\text { mutation }\end{array}$ & 8.85E-02 & 9.05E-02 & $\begin{array}{c}\text { deleterious } \\
(0.04)\end{array}$ & $\begin{array}{c}\text { probably_ } \\
\text { damag- } \\
\text { ing } \\
(0.989)\end{array}$ & \multirow[t]{2}{*}{$\begin{array}{c}\text { Compound } \\
\text { Heterozy- } \\
\text { gous }\end{array}$} & NACHT & & & \\
\hline & & $\begin{array}{c}\text { Chr19: } \\
55494913\end{array}$ & & c. $1847 \mathrm{~A}>\mathrm{T}$ & p.Glu616Val & $\begin{array}{l}\text { Missense } \\
\text { mutation }\end{array}$ & 7.96E-06 & NA & $\begin{array}{c}\text { deleterious } \\
(0.04)\end{array}$ & $\begin{array}{l}\text { benign } \\
(0.405)\end{array}$ & & Exon8 & & & \\
\hline & \multirow[t]{2}{*}{ 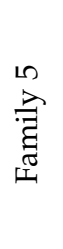 } & $\begin{array}{c}\text { Chr19: } \\
55493728\end{array}$ & & c. $662 \mathrm{C}>\mathrm{T}$ & p.Thr221Met & $\begin{array}{l}\text { Missense } \\
\text { mutation }\end{array}$ & 8.85E-02 & 9.05E-02 & $\begin{array}{c}\text { deleterious } \\
(0.04)\end{array}$ & $\begin{array}{c}\text { probably_ } \\
\text { damag- } \\
\text { ing } \\
(0.989)\end{array}$ & \multirow[t]{2}{*}{$\begin{array}{l}\text { Compound } \\
\text { Heterozy- } \\
\text { gous }\end{array}$} & NACHT & & & \\
\hline & & $\begin{array}{c}\text { Chr19: } \\
55494534\end{array}$ & & c. $1469 \mathrm{C}>\mathrm{T}$ & p.Arg490Cys & $\begin{array}{l}\text { Missense } \\
\text { mutation }\end{array}$ & $1.28 \mathrm{E}-04$ & $3.20 \mathrm{E}-05$ & $\begin{array}{c}\text { deleterious } \\
(0.01)\end{array}$ & $\begin{array}{c}\text { benign } \\
(0.03)\end{array}$ & & Exon7 & & & \\
\hline
\end{tabular}


Table 1. Cont.

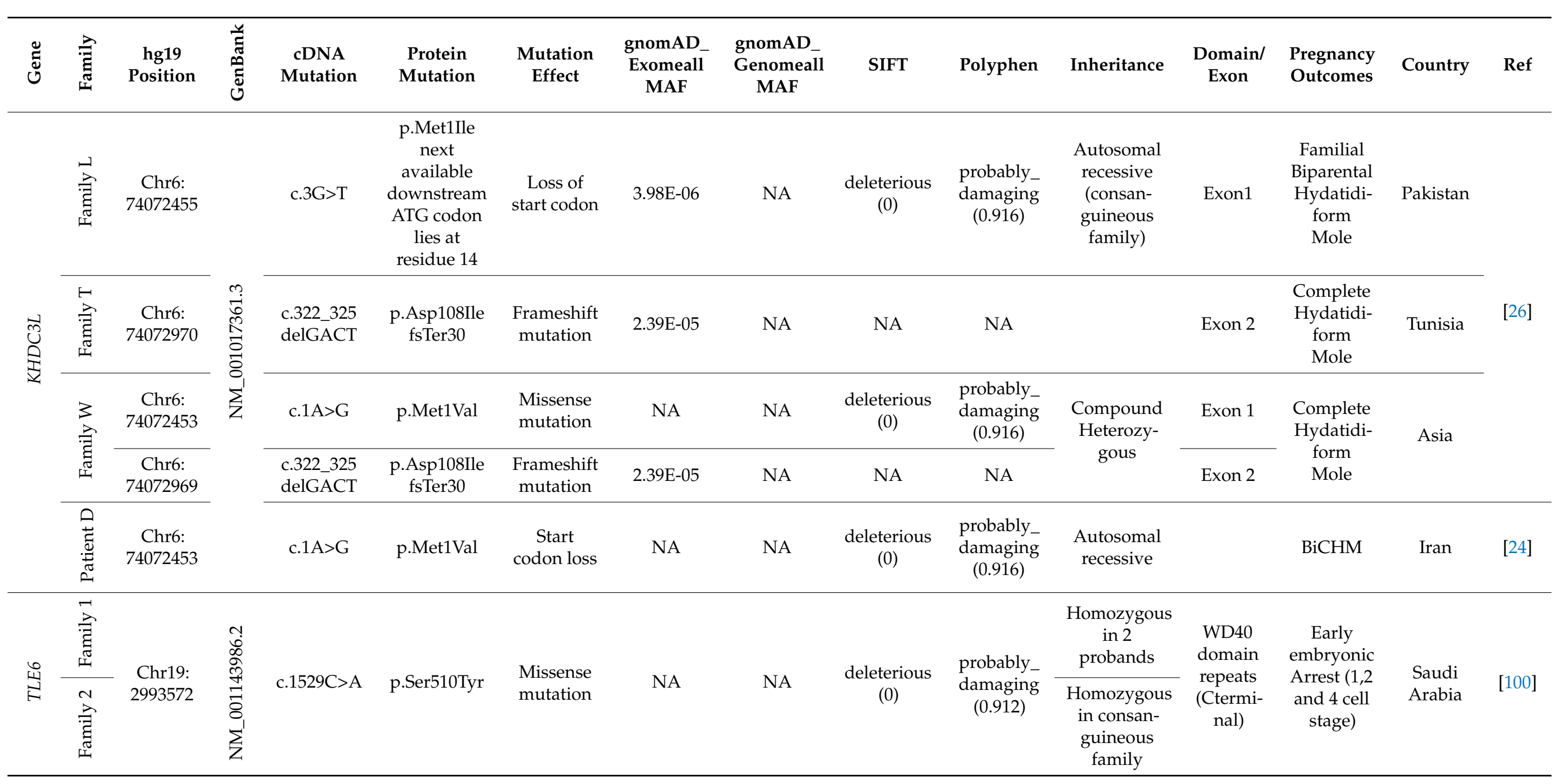


Table 1. Cont.

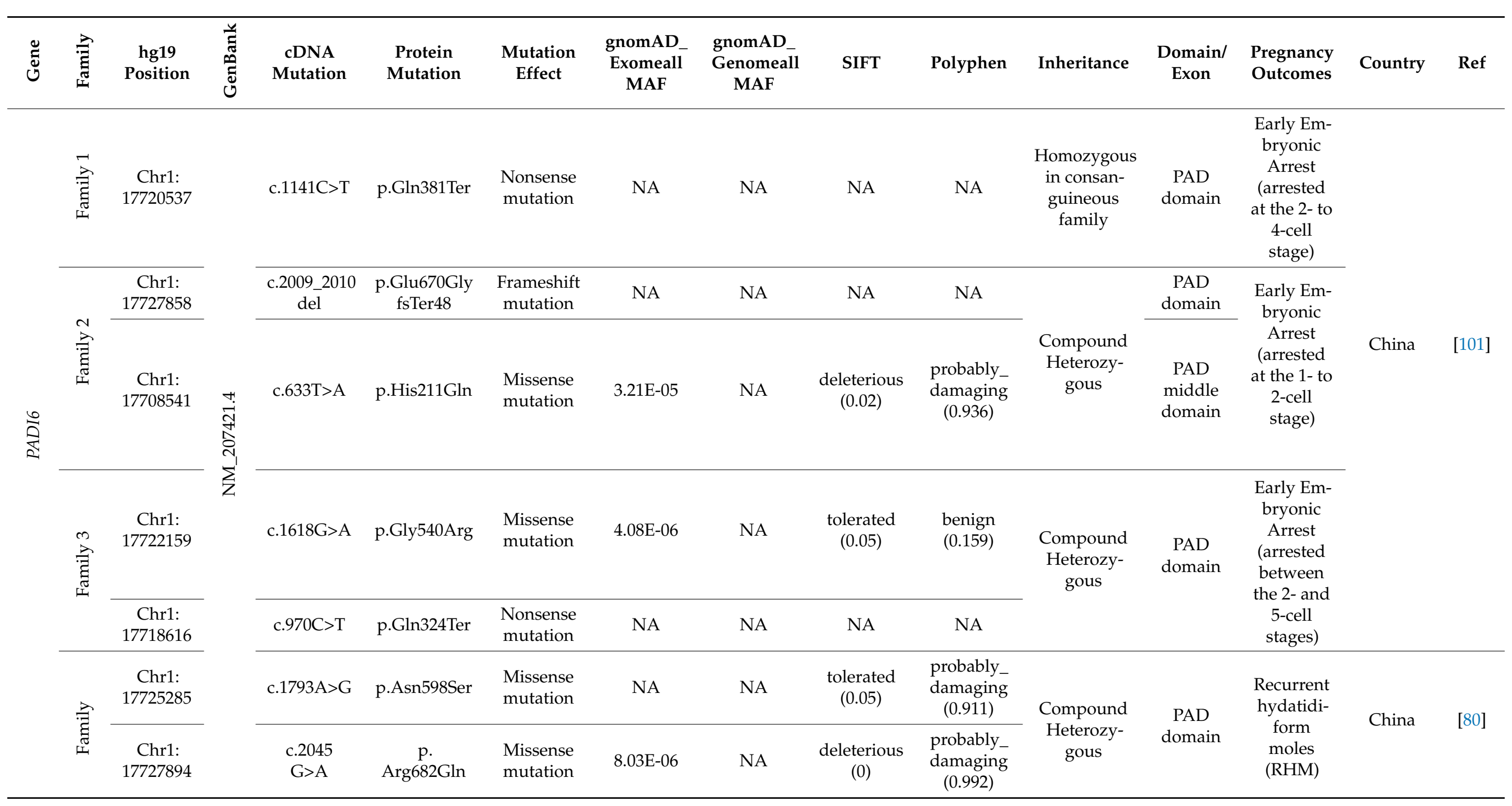


Table 1. Cont.

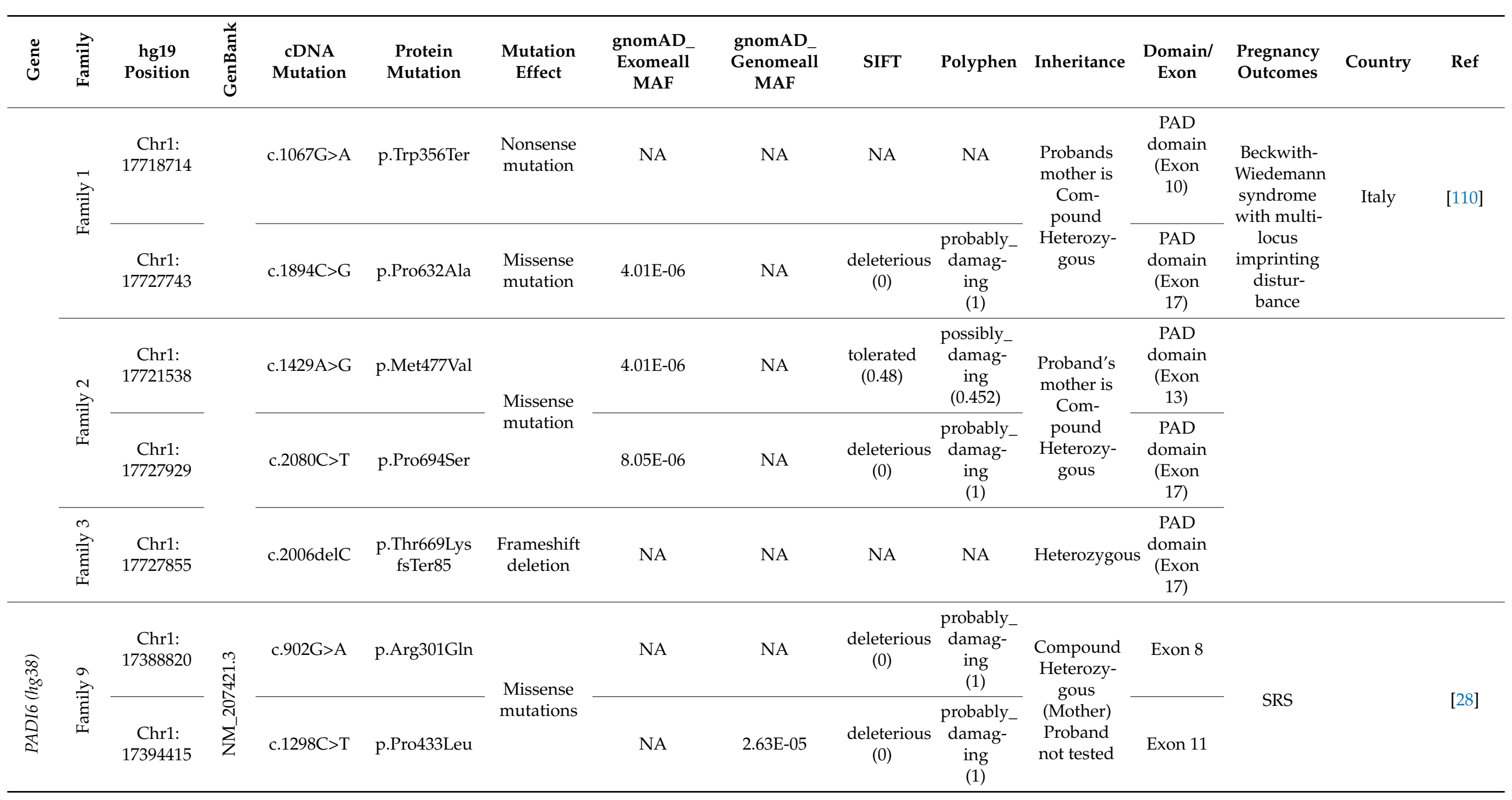


Table 1. Cont.

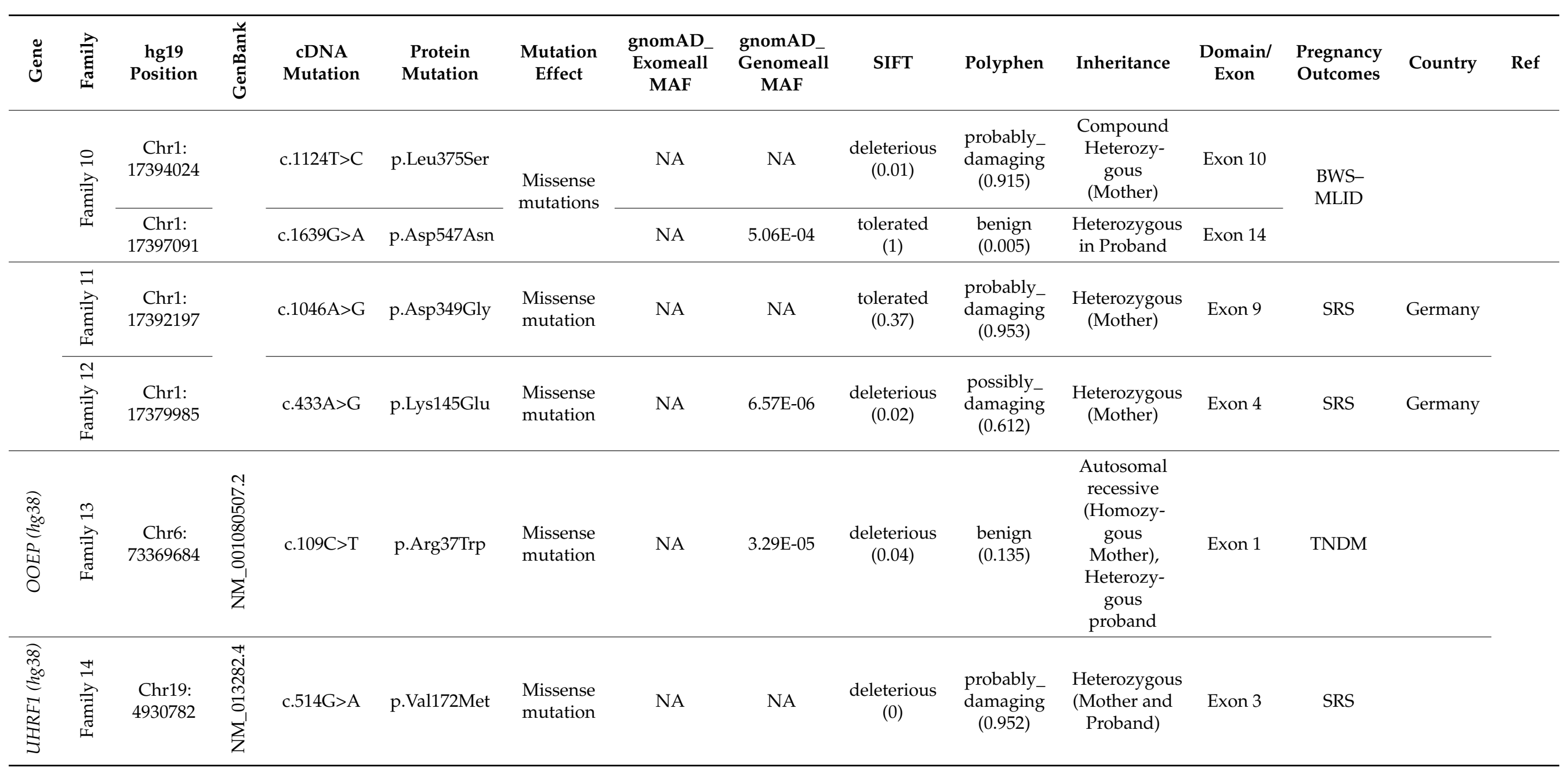


Table 1. Cont.

\begin{tabular}{|c|c|c|c|c|c|c|c|c|c|c|c|c|c|c|c|}
\hline Ёँ & 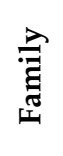 & $\begin{array}{c}\text { hg19 } \\
\text { Position }\end{array}$ & 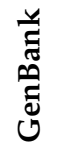 & $\begin{array}{c}\text { cDNA } \\
\text { Mutation }\end{array}$ & $\begin{array}{l}\text { Protein } \\
\text { Mutation }\end{array}$ & $\begin{array}{c}\text { Mutation } \\
\text { Effect }\end{array}$ & $\begin{array}{c}\text { gnomAD_ } \\
\text { Exomeall } \\
\text { MAF }\end{array}$ & $\begin{array}{l}\text { gnomAD_ } \\
\text { Genomeall } \\
\text { MAF }\end{array}$ & SIFT & Polyphen & Inheritance & $\begin{array}{l}\text { Domain/ } \\
\text { Exon }\end{array}$ & $\begin{array}{l}\text { Pregnancy } \\
\text { Outcomes }\end{array}$ & Country & Ref \\
\hline
\end{tabular}

The letter E is substituted for “ $\times 10^{\wedge}$ ”. Not Applicable (NA). 
DAPIN (Domain in Apoptosis and Interferon response) domain. Protein arginine deiminase (PAD), Beckwith-Wiedemann syndrome (BWS), Silver-Russell Syndrome (SRS), transient neonatal diabetes mellitus (TNDM), partial HM (PHM). Functional effects of the detected variations were predicted from SIFT, PolyPhen and CADD Phred (CADD Phred score column is provided in the supplementary Table S1). The Minor Allele Frequency (MAF) of the potential causal variants was found on The Genome Aggregation Database (gnomAD).

\section{Conclusions}

In this review, we discussed how clinical syndromes, and in particular, $\mathrm{BiCHM}$, which result from imprinting disturbances. Up to $50 \%$ of imprinting errors are caused by primary epimutations that alter DNA modifications without altering the DNA sequence. Epimutations are usually the result of post-fertilization random errors in imprinting marks, and thus, are not commonly inherited. Environmental factors, such as nutrition, physiological disturbances, such as metabolic disorders, or exposures to agents, such as endocrine disruptors may cause primary epimutations. In addition, there has been a long-standing concerns that some procedures in assisted reproductive technologies (ART) could induce epimutations. Other imprinting errors result from genetic changes, including chromosomal rearrangements, mutations (in imprinted genes or epigenetic regulators) and uniparental disomies. Here, we highlighted imprinting errors arising from mutations in epigenetic regulators such as ZFP57, as well as from maternal effect mutations in genes that encode proteins of the enigmatic SCMC. The outcomes of such mutations range from serious compromise in developmental competence of the embryo, infertility, to MLID.

To improve molecular diagnosis and clinical management of these, and related, human reproductive disorders, it will be important to improve our understanding of the causes and origin of imprinting errors. This is particularly true for maternal-effect mutations in genes that encode proteins of the SCMC, for which the mechanisms leading to imprinting errors remain obscure. As we discussed in this review, the SCMC is involved in a multitude of functions important in the oocyte and preimplantation embryo and mutations in components of this complex cause serious imprinting errors. More studies are required to disentangle the different functions of the SCMC in humans. Due to the difficulties in accessing human material, SCMC knock-out mouse models could be informative to investigate the underlying mechanisms, but it remains to be seen whether SCMC mutations in the mouse induce DNA methylation defects akin to those in BiCHM or MLID. However, these disorders demonstrate that major epigenetic defects can arise at crucial times of methylation programming and reprogramming events due to defects in factors-the SCMCthat themselves are not epigenetic regulators. This may reveal the importance of as yet undiscovered cellular processes that ensure the activity, cofactor availability or sub-cellular localization of the epigenetic machinery required for DNA methylation establishment or maintenance events. This might also identify a new domain of vulnerability of epigenetic control in the critical preimplantation period that could be sensitive to aspects of adverse maternal physiology or ART procedures.

Supplementary Materials: The following are available online at https://www.mdpi.com/article/ 10.3390/genes12081214/s1, Table S1: Summary of familial and singleton variants within SCMC genes causing early embryonic lethality, MLID, and BiCHM. The CADD Phred score is provided in this table.

Author Contributions: Conceptualization: Z.A.; writing the original draft: Z.A., I.C., H.D.; review and editing: Z.A., I.C., H.D., M.S., G.K., I.B.V.d.V.; funding acquisition: I.B.V.d.V. and G.K. All authors have read and agreed to the published version of the manuscript.

Funding: Work in GK's lab is supported by funding from the UK Biotechnology and Biological Sciences Research Council (BBS/E/B/000C0423), Medical Research Council (MR/S000437/1), and the People Programme (Marie Curie Actions) of the European Union's H2020 Programme (Research Executive Agency grant agreement number PITN-GA-2019-860960). This work in IVdV's is supported 
by grants (R01HD079442 and R01HD092746) from the Eunice Kennedy Shriver National Institute of Child Health and Human Development of the National Institutes of Health, by cores from the Intellectual and Developmental Disabilities Research Center (IDDRC; grant P50 HD103555). The content is solely the responsibility of the authors and does not necessarily represent the official views of the National Institutes of Health. M.S. is supported by postdoctoral fellowship award from The Lalor Foundation, INC.

Conflicts of Interest: The authors declare no conflict of interest.

\section{References}

1. Smith, Z.D.; Meissner, A. DNA Methylation: Roles in Mammalian Development. Nat. Rev. Genet. 2013, 14, 204-220. [CrossRef] [PubMed]

2. Zhang, Z.-M.; Lu, R.; Wang, P.; Yu, Y.; Chen, D.; Gao, L.; Liu, S.; Ji, D.; Rothbart, S.B.; Wang, Y.; et al. Structural Basis for DNMT3A-Mediated de Novo DNA Methylation. Nature 2018, 554, 387-391. [CrossRef]

3. Petrussa, L.; Van de Velde, H.; De Rycke, M. Dynamic Regulation of DNA Methyltransferases in Human Oocytes and Preimplantation Embryos after Assisted Reproductive Technologies. Mol. Hum. Reprod. 2014, 20, 861-874. [CrossRef]

4. Bostick, M.; Kim, J.K.; Estève, P.-O.; Clark, A.; Pradhan, S.; Jacobsen, S.E. UHRF1 Plays a Role in Maintaining DNA Methylation in Mammalian Cells. Science 2007, 317, 1760-1764. [CrossRef] [PubMed]

5. Shirane, K.; Toh, H.; Kobayashi, H.; Miura, F.; Chiba, H.; Ito, T.; Kono, T.; Sasaki, H. Mouse Oocyte Methylomes at Base Resolution Reveal Genome-Wide Accumulation of Non-CpG Methylation and Role of DNA Methyltransferases. PLoS Genet. 2013, 9, e1003439. [CrossRef] [PubMed]

6. Messerschmidt, D.M.; Knowles, B.B.; Solter, D. DNA Methylation Dynamics during Epigenetic Reprogramming in the Germline and Preimplantation Embryos. Genes Dev. 2014, 28, 812-828. [CrossRef]

7. Hajkova, P.; Erhardt, S.; Lane, N.; Haaf, T.; El-Maarri, O.; Reik, W.; Walter, J.; Surani, M.A. Epigenetic Reprogramming in Mouse Primordial Germ Cells. Mech. Dev. 2002, 117, 15-23. [CrossRef]

8. Henckel, A.; Chebli, K.; Kota, S.K.; Arnaud, P.; Feil, R. Transcription and histone methylation changes correlate with imprint acquisition in male germ cells. EMBO J. 2012, 31, 606-615. [CrossRef] [PubMed]

9. Guo, H.; Zhu, P.; Wu, X.; Li, X.; Wen, L.; Tang, F. Single-Cell Methylome Landscapes of Mouse Embryonic Stem Cells and Early Embryos Analyzed Using Reduced Representation Bisulfite Sequencing. Genome Res. 2013, 23, 2126-2135. [CrossRef] [PubMed]

10. Stewart, K.R.; Veselovska, L.; Kelsey, G. Establishment and Functions of DNA Methylation in the Germline. Epigenomics 2016, 8 , 1399-1413. [CrossRef] [PubMed]

11. Smallwood, S.A.; Tomizawa, S.-I.; Krueger, F.; Ruf, N.; Carli, N.; Segonds-Pichon, A.; Sato, S.; Hata, K.; Andrews, S.R.; Kelsey, G. Dynamic CpG Island Methylation Landscape in Oocytes and Preimplantation Embryos. Nat. Genet. 2011, 43, 811-814. [CrossRef]

12. Kobayashi, H.; Sakurai, T.; Imai, M.; Takahashi, N.; Fukuda, A.; Yayoi, O.; Sato, S.; Nakabayashi, K.; Hata, K.; Sotomaru, Y.; et al. Contribution of Intragenic DNA Methylation in Mouse Gametic DNA Methylomes to Establish Oocyte-Specific Heritable Marks. PLoS Genet. 2012, 8, e1002440. [CrossRef]

13. Okae, H.; Chiba, H.; Hiura, H.; Hamada, H.; Sato, A.; Utsunomiya, T.; Kikuchi, H.; Yoshida, H.; Tanaka, A.; Suyama, M.; et al. Genome-Wide Analysis of DNA Methylation Dynamics during Early Human Development. PLoS Genet. 2014, 10, e1004868. [CrossRef]

14. Veselovska, L.; Smallwood, S.A.; Saadeh, H.; Stewart, K.R.; Krueger, F.; Maupetit-Méhouas, S.; Arnaud, P.; Tomizawa, S.-I.; Andrews, S.; Kelsey, G. Deep Sequencing and de Novo Assembly of the Mouse Oocyte Transcriptome Define the Contribution of Transcription to the DNA Methylation Landscape. Genome Biol. 2015, 16, 209. [CrossRef]

15. Santos, F.; Hendrich, B.; Reik, W.; Dean, W. Dynamic Reprogramming of DNA Methylation in the Early Mouse Embryo. Dev. Biol. 2002, 241, 172-182. [CrossRef] [PubMed]

16. Gu, T.-P.; Guo, F.; Yang, H.; Wu, H.-P.; Xu, G.-F.; Liu, W.; Xie, Z.-G.; Shi, L.; He, X.; Jin, S.; et al. The Role of Tet3 DNA Dioxygenase in Epigenetic Reprogramming by Oocytes. Nature 2011, 477, 606-610. [CrossRef] [PubMed]

17. Smallwood, S.A.; Kelsey, G. De Novo DNA Methylation: A Germ Cell Perspective. Trends Genet. 2012, 28, 33-42. [CrossRef] [PubMed]

18. Amouroux, R.; Nashun, B.; Shirane, K.; Nakagawa, S.; Hill, P.W.; D'Souza, Z.; Nakayama, M.; Matsuda, M.; Turp, A.; Ndjetehe, E.; et al. De Novo DNA Methylation Drives 5hmC Accumulation in Mouse Zygotes. Nat. Cell Biol. 2016, 18, $225-233$. [CrossRef]

19. Zhu, P.; Guo, H.; Ren, Y.; Hou, Y.; Dong, J.; Li, R.; Lian, Y.; Fan, X.; Hu, B.; Gao, Y.; et al. Single-Cell DNA Methylome Sequencing of Human Preimplantation Embryos. Nat. Genet. 2018, 50, 12-19. [CrossRef]

20. Barlow, D.P.; Bartolomei, M.S. Genomic Imprinting in Mammals. Cold Spring Harb. Perspect. Biol. 2014, 6, a018382. [CrossRef]

21. Monk, D.; Mackay, D.J.G.; Eggermann, T.; Maher, E.R.; Riccio, A. Genomic Imprinting Disorders: Lessons on How Genome, Epigenome and Environment Interact. Nat. Rev. Genet. 2019, 20, 235-248. [CrossRef]

22. Soellner, L.; Begemann, M.; Mackay, D.J.G.; Grønskov, K.; Tümer, Z.; Maher, E.R.; Temple, I.K.; Monk, D.; Riccio, A.; Linglart, A.; et al. Recent Advances in Imprinting Disorders. Clin. Genet. 2017, 91, 3-13. [CrossRef] [PubMed]

23. Van den Veyver, I.B.; Al-Hussaini, T.K. Biparental Hydatidiform Moles: A Maternal Effect Mutation Affecting Imprinting in the Offspring. Hum. Reprod. Update 2006, 12, 233-242. [CrossRef] 
24. Demond, H.; Anvar, Z.; Jahromi, B.N.; Sparago, A.; Verma, A.; Davari, M.; Calzari, L.; Russo, S.; Jahromi, M.A.; Monk, D.; et al. A KHDC3L Mutation Resulting in Recurrent Hydatidiform Mole Causes Genome-Wide DNA Methylation Loss in Oocytes and Persistent Imprinting Defects Post-Fertilisation. Genome Med. 2019, 11, 84. [CrossRef] [PubMed]

25. Murdoch, S.; Djuric, U.; Mazhar, B.; Seoud, M.; Khan, R.; Kuick, R.; Bagga, R.; Kircheisen, R.; Ao, A.; Ratti, B.; et al. Mutations in NALP7 Cause Recurrent Hydatidiform Moles and Reproductive Wastage in Humans. Nat. Genet. 2006, 38, 300-302. [CrossRef] [PubMed]

26. Parry, D.A.; Logan, C.V.; Hayward, B.E.; Shires, M.; Landolsi, H.; Diggle, C.; Carr, I.; Rittore, C.; Touitou, I.; Philibert, L.; et al. Mutations Causing Familial Biparental Hydatidiform Mole Implicate C6orf221 as a Possible Regulator of Genomic Imprinting in the Human Oocyte. Am. J. Hum. Genet. 2011, 89, 451-458. [CrossRef]

27. Docherty, L.E.; Rezwan, F.I.; Poole, R.L.; Turner, C.L.S.; Kivuva, E.; Maher, E.R.; Smithson, S.F.; Hamilton-Shield, J.P.; Patalan, M.; Gizewska, M.; et al. Mutations in NLRP5 Are Associated with Reproductive Wastage and Multilocus Imprinting Disorders in Humans. Nat. Commun. 2015, 6, 8086. [CrossRef]

28. Begemann, M.; Rezwan, F.I.; Beygo, J.; Docherty, L.E.; Kolarova, J.; Schroeder, C.; Buiting, K.; Chokkalingam, K.; Degenhardt, F.; Wakeling, E.L.; et al. Maternal Variants in NLRP and Other Maternal Effect Proteins Are Associated with Multilocus Imprinting Disturbance in Offspring. J. Med. Genet. 2018, 55, 497-504. [CrossRef]

29. Tong, Z.B.; Gold, L.; Pfeifer, K.E.; Dorward, H.; Lee, E.; Bondy, C.A.; Dean, J.; Nelson, L.M. Mater, a Maternal Effect Gene Required for Early Embryonic Development in Mice. Nat. Genet. 2000, 26, 267-268. [CrossRef]

30. Saitou, M.; Miyauchi, H. Gametogenesis from Pluripotent Stem Cells. Cell Stem Cell 2016, 18, 721-735. [CrossRef] [PubMed]

31. Irie, N.; Weinberger, L.; Tang, W.W.C.; Kobayashi, T.; Viukov, S.; Manor, Y.S.; Dietmann, S.; Hanna, J.H.; Surani, M.A. SOX17 Is a Critical Specifier of Human Primordial Germ Cell Fate. Cell 2015, 160, 253-268. [CrossRef]

32. Tang, W.W.C.; Dietmann, S.; Irie, N.; Leitch, H.G.; Floros, V.I.; Bradshaw, C.R.; Hackett, J.A.; Chinnery, P.F.; Surani, M.A. A Unique Gene Regulatory Network Resets the Human Germline Epigenome for Development. Cell 2015, 161, 1453-1467. [CrossRef] [PubMed]

33. Guo, F.; Yan, L.; Guo, H.; Li, L.; Hu, B.; Zhao, Y.; Yong, J.; Hu, Y.; Wang, X.; Wei, Y.; et al. The Transcriptome and DNA Methylome Landscapes of Human Primordial Germ Cells. Cell 2015, 161, 1437-1452. [CrossRef] [PubMed]

34. Yan, R.; Gu, C.; You, D.; Huang, Z.; Qian, J.; Yang, Q.; Cheng, X.; Zhang, L.; Wang, H.; Wang, P.; et al. Decoding Dynamic Epigenetic Landscapes in Human Oocytes Using Single-Cell Multi-Omics Sequencing. Cell Stem Cell 2021. [CrossRef] [PubMed]

35. Bourc'his, D.; Xu, G.L.; Lin, C.S.; Bollman, B.; Bestor, T.H. Dnmt3L and the Establishment of Maternal Genomic Imprints. Science 2001, 294, 2536-2539. [CrossRef] [PubMed]

36. Kaneda, M.; Hirasawa, R.; Chiba, H.; Okano, M.; Li, E.; Sasaki, H. Genetic Evidence for Dnmt3a-Dependent Imprinting during Oocyte Growth Obtained by Conditional Knockout with Zp3-Cre and Complete Exclusion of Dnmt3b by Chimera Formation. Genes Cells 2010, 15, 169-179. [CrossRef]

37. Demond, H.; Kelsey, G. The Enigma of DNA Methylation in the Mammalian Oocyte. F1000Res 2020, 9, 146. [CrossRef] [PubMed]

38. Guo, H.; Zhu, P.; Yan, L.; Li, R.; Hu, B.; Lian, Y.; Yan, J.; Ren, X.; Lin, S.; Li, J.; et al. The DNA Methylation Landscape of Human Early Embryos. Nature 2014, 511, 606-610. [CrossRef]

39. Brind'Amour, J.; Kobayashi, H.; Richard Albert, J.; Shirane, K.; Sakashita, A.; Kamio, A.; Bogutz, A.; Koike, T.; Karimi, M.M.; Lefebvre, L.; et al. LTR Retrotransposons Transcribed in Oocytes Drive Species-Specific and Heritable Changes in DNA Methylation. Nat. Commun. 2018, 9, 3331. [CrossRef]

40. Gu, C.; Liu, S.; Wu, Q.; Zhang, L.; Guo, F. Integrative Single-Cell Analysis of Transcriptome, DNA Methylome and Chromatin Accessibility in Mouse Oocytes. Cell Res. 2019, 29, 110-123. [CrossRef] [PubMed]

41. Gougeon, A. Dynamics of Follicular Growth in the Human: A Model from Preliminary Results. Hum. Reprod. 1986, 1, 81-87. [CrossRef] [PubMed]

42. Hanna, C.W.; Demond, H.; Kelsey, G. Epigenetic Regulation in Development: Is the Mouse a Good Model for the Human? Hum. Reprod. Update 2018, 24, 556-576. [CrossRef] [PubMed]

43. Seisenberger, S.; Peat, J.R.; Hore, T.A.; Santos, F.; Dean, W.; Reik, W. Reprogramming DNA Methylation in the Mammalian Life Cycle: Building and Breaking Epigenetic Barriers. Philos. Trans. R. Soc. B Biol. Sci. 2013, 368, 20110330. [CrossRef]

44. Galan, A.; Diaz-Gimeno, P.; Poo, M.E.; Valbuena, D.; Sanchez, E.; Ruiz, V.; Dopazo, J.; Montaner, D.; Conesa, A.; Simon, C. Defining the Genomic Signature of Totipotency and Pluripotency during Early Human Development. PLoS ONE 2013, 8, e62135. [CrossRef]

45. Yan, L.; Yang, M.; Guo, H.; Yang, L.; Wu, J.; Li, R.; Liu, P.; Lian, Y.; Zheng, X.; Yan, J.; et al. Single-Cell RNA-Seq Profiling of Human Preimplantation Embryos and Embryonic Stem Cells. Nat. Struct. Mol. Biol. 2013, 20, 1131-1139. [CrossRef] [PubMed]

46. Dobson, A.T.; Raja, R.; Abeyta, M.J.; Taylor, T.; Shen, S.; Haqq, C.; Pera, R.A.R. The Unique Transcriptome through Day 3 of Human Preimplantation Development. Hum. Mol. Genet. 2004, 13, 1461-1470. [CrossRef] [PubMed]

47. Hamada, H.; Okae, H.; Toh, H.; Chiba, H.; Hiura, H.; Shirane, K.; Sato, T.; Suyama, M.; Yaegashi, N.; Sasaki, H.; et al. AlleleSpecific Methylome and Transcriptome Analysis Reveals Widespread Imprinting in the Human Placenta. Am. J. Hum. Genet. 2016, 99, 1045-1058. [CrossRef]

48. Smith, Z.D.; Chan, M.M.; Humm, K.C.; Karnik, R.; Mekhoubad, S.; Regev, A.; Eggan, K.; Meissner, A. DNA Methylation Dynamics of the Human Preimplantation Embryo. Nature 2014, 511, 611-615. [CrossRef] 
49. Gerdes, P.; Richardson, S.R.; Mager, D.L.; Faulkner, G.J. Transposable Elements in the Mammalian Embryo: Pioneers Surviving through Stealth and Service. Genome Biol. 2016, 17, 100. [CrossRef]

50. Tan, K.; Zhang, Z.; Miao, K.; Yu, Y.; Sui, L.; Tian, J.; An, L. Dynamic Integrated Analysis of DNA Methylation and Gene Expression Profiles in in Vivo and in Vitro Fertilized Mouse Post-Implantation Extraembryonic and Placental Tissues. Mol. Hum. Reprod. 2016, 22, 485-498. [CrossRef]

51. Zeng, Y.; Chen, T. DNA Methylation Reprogramming during Mammalian Development. Genes 2019, 10, 257. [CrossRef]

52. Dahlet, T.; Argüeso Lleida, A.; Al Adhami, H.; Dumas, M.; Bender, A.; Ngondo, R.P.; Tanguy, M.; Vallet, J.; Auclair, G.; Bardet, A.F.; et al. Genome-Wide Analysis in the Mouse Embryo Reveals the Importance of DNA Methylation for Transcription Integrity. Nat. Commun. 2020, 11, 3153. [CrossRef] [PubMed]

53. Christodoulou, N.; Weberling, A.; Strathdee, D.; Anderson, K.I.; Timpson, P.; Zernicka-Goetz, M. Morphogenesis of ExtraEmbryonic Tissues Directs the Remodelling of the Mouse Embryo at Implantation. Nat. Commun. 2019, 10, 3557. [CrossRef] [PubMed]

54. Hanna, C.W.; Peñaherrera, M.S.; Saadeh, H.; Andrews, S.; McFadden, D.E.; Kelsey, G.; Robinson, W.P. Pervasive Polymorphic Imprinted Methylation in the Human Placenta. Genome Res. 2016, 26, 756-767. [CrossRef] [PubMed]

55. Camprubí, C.; Iglesias-Platas, I.; Martin-Trujillo, A.; Salvador-Alarcon, C.; Rodriguez, M.A.; Barredo, D.R.; Court, F.; Monk, D. Stability of Genomic Imprinting and Gestational-Age Dynamic Methylation in Complicated Pregnancies Conceived Following Assisted Reproductive Technologies. Biol. Reprod. 2013, 89, 50. [CrossRef] [PubMed]

56. Schroeder, D.I.; Blair, J.D.; Lott, P.; Yu, H.O.K.; Hong, D.; Crary, F.; Ashwood, P.; Walker, C.; Korf, I.; Robinson, W.P.; et al. The Human Placenta Methylome. Proc. Natl. Acad. Sci. USA 2013, 110, 6037-6042. [CrossRef]

57. Peters, J. The Role of Genomic Imprinting in Biology and Disease: An Expanding View. Nat. Rev. Genet. 2014, 15, 517-530. [CrossRef] [PubMed]

58. Bartolomei, M.S.; Ferguson-Smith, A.C. Mammalian Genomic Imprinting. Cold Spring Harb. Perspect. Biol. 2011, 3, a00259. [CrossRef]

59. Inoue, A.; Jiang, L.; Lu, F.; Suzuki, T.; Zhang, Y. Maternal H3K27me3 Controls DNA Methylation-Independent Imprinting. Nature 2017, 547, 419-424. [CrossRef]

60. Chen, Z.; Zhang, Y. Maternal H3K27me3-Dependent Autosomal and X Chromosome Imprinting. Nat. Rev. Genet. 2020, 21, 555-571. [CrossRef]

61. Hanna, C.W. Placental Imprinting: Emerging Mechanisms and Functions. PLoS Genet. 2020, 16, e1008709. [CrossRef]

62. Abramowitz, L.K.; Bartolomei, M.S. Genomic Imprinting: Recognition and Marking of Imprinted Loci. Curr. Opin. Genet. Dev. 2012, 22, 72-78. [CrossRef]

63. Li, X.; Ito, M.; Zhou, F.; Youngson, N.; Zuo, X.; Leder, P.; Ferguson-Smith, A.C. A Maternal-Zygotic Effect Gene, Zfp57, Maintains Both Maternal and Paternal Imprints. Dev. Cell 2008, 15, 547-557. [CrossRef]

64. Quenneville, S.; Verde, G.; Corsinotti, A.; Kapopoulou, A.; Jakobsson, J.; Offner, S.; Baglivo, I.; Pedone, P.V.; Grimaldi, G.; Riccio, A.; et al. In Embryonic Stem Cells, ZFP57/KAP1 Recognize a Methylated Hexanucleotide to Affect Chromatin and DNA Methylation of Imprinting Control Regions. Mol. Cell 2011, 44, 361-372. [CrossRef] [PubMed]

65. Monteagudo-Sánchez, A.; Hernandez Mora, J.R.; Simon, C.; Burton, A.; Tenorio, J.; Lapunzina, P.; Clark, S.; Esteller, M.; Kelsey, G.; López-Siguero, J.P.; et al. The Role of ZFP57 and Additional KRAB-Zinc Finger Proteins in the Maintenance of Human Imprinted Methylation and Multi-Locus Imprinting Disturbances. Nucleic Acids Res. 2020, 48, 11394-11407. [CrossRef]

66. Mackay, D.J.G.; Callaway, J.L.A.; Marks, S.M.; White, H.E.; Acerini, C.L.; Boonen, S.E.; Dayanikli, P.; Firth, H.V.; Goodship, J.A.; Haemers, A.P.; et al. Hypomethylation of Multiple Imprinted Loci in Individuals with Transient Neonatal Diabetes Is Associated with Mutations in ZFP57. Nat. Genet. 2008, 40, 949-951. [CrossRef] [PubMed]

67. Takahashi, N.; Coluccio, A.; Thorball, C.W.; Planet, E.; Shi, H.; Offner, S.; Turelli, P.; Imbeault, M.; Ferguson-Smith, A.C.; Trono, D. ZNF445 Is a Primary Regulator of Genomic Imprinting. Genes Dev. 2019, 33, 49-54. [CrossRef] [PubMed]

68. Kagami, M.; Hara-Isono, K.; Matsubara, K.; Nakabayashi, K.; Narumi, S.; Fukami, M.; Ohkubo, Y.; Saitsu, H.; Takada, S.; Ogata, T. ZNF445: A homozygous truncating variant in a patient with Temple syndrome and multilocus imprinting disturbance. Clin. Epigenetics 2021, 13, 119. [CrossRef]

69. Court, F.; Tayama, C.; Romanelli, V.; Martin-Trujillo, A.; Iglesias-Platas, I.; Okamura, K.; Sugahara, N.; Simón, C.; Moore, H.; Harness, J.V.; et al. Genome-Wide Parent-of-Origin DNA Methylation Analysis Reveals the Intricacies of Human Imprinting and Suggests a Germline Methylation-Independent Mechanism of Establishment. Genome Res. 2014, 24, 554-569. [CrossRef]

70. Hanna, C.W.; Kelsey, G. The Specification of Imprints in Mammals. Heredity 2014, 113, 176-183. [CrossRef]

71. Sanchez-Delgado, M.; Court, F.; Vidal, E.; Medrano, J.; Monteagudo-Sánchez, A.; Martin-Trujillo, A.; Tayama, C.; Iglesias-Platas, I.; Kondova, I.; Bontrop, R.; et al. Human Oocyte-Derived Methylation Differences Persist in the Placenta Revealing Widespread Transient Imprinting. PLoS Genet. 2016, 12, e1006427. [CrossRef] [PubMed]

72. Yuen, R.K.; Jiang, R.; Peñaherrera, M.S.; McFadden, D.E.; Robinson, W.P. Genome-Wide Mapping of Imprinted Differentially Methylated Regions by DNA Methylation Profiling of Human Placentas from Triploidies. Epigenetics Chromatin $2011,4,10$. [CrossRef]

73. Barbaux, S.; Gascoin-Lachambre, G.; Buffat, C.; Monnier, P.; Mondon, F.; Tonanny, M.-B.; Pinard, A.; Auer, J.; Bessières, B.; Barlier, A.; et al. A Genome-Wide Approach Reveals Novel Imprinted Genes Expressed in the Human Placenta. Epigenetics 2012, 7, 1079-1090. [CrossRef] [PubMed] 
74. Hemberger, M.; Hanna, C.W.; Dean, W. Mechanisms of Early Placental Development in Mouse and Humans. Nat. Rev. Genet. 2020, 21, 27-43. [CrossRef] [PubMed]

75. Elbracht, M.; Mackay, D.; Begemann, M.; Kagan, K.O.; Eggermann, T. Disturbed Genomic Imprinting and Its Relevance for Human Reproduction: Causes and Clinical Consequences. Hum. Reprod. Update 2020, 26, 197-213. [CrossRef] [PubMed]

76. Moein-Vaziri, N.; Fallahi, J.; Namavar-Jahromi, B.; Fardaei, M.; Momtahan, M.; Anvar, Z. Clinical and Genetic-Epignetic Aspects of Recurrent Hydatidiform Mole: A Review of Literature. Taiwan. J. Obstet. Gynecol. 2018, 57, 1-6. [CrossRef]

77. Surani, M.A.; Barton, S.C.; Norris, M.L. Development of Reconstituted Mouse Eggs Suggests Imprinting of the Genome during Gametogenesis. Nature 1984, 308, 548-550. [CrossRef]

78. McGrath, J.; Solter, D. Completion of Mouse Embryogenesis Requires Both the Maternal and Paternal Genomes. Cell 1984, 37, 179-183. [CrossRef]

79. Li, Z.-K.; Wang, L.-Y.; Wang, L.-B.; Feng, G.-H.; Yuan, X.-W.; Liu, C.; Xu, K.; Li, Y.-H.; Wan, H.-F.; Zhang, Y.; et al. Generation of Bimaternal and Bipaternal Mice from Hypomethylated Haploid ESCs with Imprinting Region Deletions. Cell Stem Cell 2018, 23, 665-676.e4. [CrossRef]

80. Qian, J.; Nguyen, N.M.P.; Rezaei, M.; Huang, B.; Tao, Y.; Zhang, X.; Cheng, Q.; Yang, H.; Asangla, A.; Majewski, J.; et al. Biallelic PADI6 Variants Linking Infertility, Miscarriages, and Hydatidiform Moles. Eur. J. Hum. Genet. 2018, 26, 1007-1013. [CrossRef]

81. Judson, H.; Hayward, B.E.; Sheridan, E.; Bonthron, D.T. A Global Disorder of Imprinting in the Human Female Germ Line. Nature 2002, 416, 539-542. [CrossRef]

82. El-Maarri, O.; Seoud, M.; Coullin, P.; Herbiniaux, U.; Oldenburg, J.; Rouleau, G.; Slim, R. Maternal Alleles Acquiring Paternal Methylation Patterns in Biparental Complete Hydatidiform Moles. Hum. Mol. Genet. 2003, 12, 1405-1413. [CrossRef]

83. Kou, Y.C.; Shao, L.; Peng, H.H.; Rosetta, R.; del Gaudio, D.; Wagner, A.F.; Al-Hussaini, T.K.; Van den Veyver, I.B. A Recurrent Intragenic Genomic Duplication, Other Novel Mutations in NLRP7 and Imprinting Defects in Recurrent Biparental Hydatidiform Moles. Mol. Hum. Reprod. 2008, 14, 33-40. [CrossRef]

84. Sanchez-Delgado, M.; Martin-Trujillo, A.; Tayama, C.; Vidal, E.; Esteller, M.; Iglesias-Platas, I.; Deo, N.; Barney, O.; Maclean, K.; Hata, K.; et al. Absence of Maternal Methylation in Biparental Hydatidiform Moles from Women with NLRP7 Maternal-Effect Mutations Reveals Widespread Placenta-Specific Imprinting. PLoS Genet. 2015, 11, e1005644. [CrossRef]

85. Zhu, K.; Yan, L.; Zhang, X.; Lu, X.; Wang, T.; Yan, J.; Liu, X.; Qiao, J.; Li, L. Identification of a Human Subcortical Maternal Complex. Mol. Hum. Reprod. 2015, 21, 320-329. [CrossRef] [PubMed]

86. Li, L.; Baibakov, B.; Dean, J. A Subcortical Maternal Complex Essential for Preimplantation Mouse Embryogenesis. Dev. Cell 2008, 15, 416-425. [CrossRef]

87. Lu, X.; Gao, Z.; Qin, D.; Li, L. A Maternal Functional Module in the Mammalian Oocyte-To-Embryo Transition. Trends Mol. Med. 2017, 23, 1014-1023. [CrossRef] [PubMed]

88. Bebbere, D.; Masala, L.; Albertini, D.F.; Ledda, S. The Subcortical Maternal Complex: Multiple Functions for One Biological Structure? J. Assist. Reprod. Genet. 2016, 33, 1431-1438. [CrossRef]

89. Monk, D.; Sanchez-Delgado, M.; Fisher, R. NLRPs, the Subcortical Maternal Complex and Genomic Imprinting. Reproduction 2017, 154, R161-R170. [CrossRef] [PubMed]

90. Akoury, E.; Zhang, L.; Ao, A.; Slim, R. NLRP7 and KHDC3L, the Two Maternal-Effect Proteins Responsible for Recurrent Hydatidiform Moles, Co-Localize to the Oocyte Cytoskeleton. Hum. Reprod. 2015, 30, 159-169. [CrossRef]

91. Qian, J.; Cheng, Q.; Murdoch, S.; Xu, C.; Jin, F.; Chebaro, W.; Zhang, X.; Gao, H.; Zhu, Y.; Slim, R.; et al. The Genetics of Recurrent Hydatidiform Moles in China: Correlations between NLRP7 Mutations, Molar Genotypes and Reproductive Outcomes. Mol. Hum. Reprod. 2011, 17, 612-619. [CrossRef] [PubMed]

92. Meyer, E.; Lim, D.; Pasha, S.; Tee, L.J.; Rahman, F.; Yates, J.R.W.; Woods, C.G.; Reik, W.; Maher, E.R. Germline Mutation in NLRP2 (NALP2) in a Familial Imprinting Disorder (Beckwith-Wiedemann Syndrome). PLoS Genet. 2009, 5, e1000423. [CrossRef]

93. Messerschmidt, D.M. Should I Stay or Should I Go: Protection and Maintenance of DNA Methylation at Imprinted Genes. Epigenetics 2012, 7, 969-975. [CrossRef] [PubMed]

94. Mahadevan, S.; Sathappan, V.; Utama, B.; Lorenzo, I.; Kaskar, K.; Van den Veyver, I.B. Maternally Expressed NLRP2 Links the Subcortical Maternal Complex (SCMC) to Fertility, Embryogenesis and Epigenetic Reprogramming. Sci. Rep. 2017, 7, 44667. [CrossRef]

95. Tian, X.; Pascal, G.; Monget, P. Evolution and Functional Divergence of NLRP Genes in Mammalian Reproductive Systems. BMC Evol. Biol. 2009, 9, 202. [CrossRef]

96. Zheng, P.; Dean, J. Role of Filia, a Maternal Effect Gene, in Maintaining Euploidy during Cleavage-Stage Mouse Embryogenesis. Proc. Natl. Acad. Sci. USA 2009, 106, 7473-7478. [CrossRef] [PubMed]

97. Yu, X.-J.; Yi, Z.; Gao, Z.; Qin, D.; Zhai, Y.; Chen, X.; Ou-Yang, Y.; Wang, Z.-B.; Zheng, P.; Zhu, M.-S.; et al. The Subcortical Maternal Complex Controls Symmetric Division of Mouse Zygotes by Regulating F-Actin Dynamics. Nat. Commun. 2014, 5, 4887. [CrossRef]

98. Tashiro, F.; Kanai-Azuma, M.; Miyazaki, S.; Kato, M.; Tanaka, T.; Toyoda, S.; Yamato, E.; Kawakami, H.; Miyazaki, T.; Miyazaki, J.-I. Maternal-Effect Gene Ces5/Ooep/Moep19/Floped Is Essential for Oocyte Cytoplasmic Lattice Formation and Embryonic Development at the Maternal-Zygotic Stage Transition. Genes Cells 2010, 15, 813-828. [CrossRef]

99. Kaneda, M.; Okano, M.; Hata, K.; Sado, T.; Tsujimoto, N.; Li, E.; Sasaki, H. Essential Role for de Novo DNA Methyltransferase Dnmt3a in Paternal and Maternal Imprinting. Nature 2004, 429, 900-903. [CrossRef] [PubMed] 
100. Alazami, A.M.; Awad, S.M.; Coskun, S.; Al-Hassan, S.; Hijazi, H.; Abdulwahab, F.M.; Poizat, C.; Alkuraya, F.S. TLE6 Mutation Causes the Earliest Known Human Embryonic Lethality. Genome Biol. 2015, 16, 240. [CrossRef]

101. Xu, Y.; Shi, Y.; Fu, J.; Yu, M.; Feng, R.; Sang, Q.; Liang, B.; Chen, B.; Qu, R.; Li, B.; et al. Mutations in PADI6 Cause Female Infertility Characterized by Early Embryonic Arrest. Am. J. Hum. Genet. 2016, 99, 744-752. [CrossRef]

102. Maddirevula, S.; Coskun, S.; Alhassan, S.; Elnour, A.; Alsaif, H.S.; Ibrahim, N.; Abdulwahab, F.; Arold, S.T.; Alkuraya, F.S. Female Infertility Caused by Mutations in the Oocyte-Specific Translational Repressor PATL2. Am. J. Hum. Genet. 2017, 101, 603-608. [CrossRef]

103. Wang, X.; Song, D.; Mykytenko, D.; Kuang, Y.; Lv, Q.; Li, B.; Chen, B.; Mao, X.; Xu, Y.; Zukin, V.; et al. Novel Mutations in Genes Encoding Subcortical Maternal Complex Proteins May Cause Human Embryonic Developmental Arrest. Reprod. Biomed. Online 2018, 36, 698-704. [CrossRef]

104. Mu, J.; Wang, W.; Chen, B.; Wu, L.; Li, B.; Mao, X.; Zhang, Z.; Fu, J.; Kuang, Y.; Sun, X.; et al. Mutations in NLRP2 and NLRP5 Cause Female Infertility Characterised by Early Embryonic Arrest. J. Med. Genet. 2019, 56, 471-480. [CrossRef]

105. Deveault, C.; Qian, J.H.; Chebaro, W.; Ao, A.; Gilbert, L.; Mehio, A.; Khan, R.; Tan, S.L.; Wischmeijer, A.; Coullin, P.; et al. NLRP7 Mutations in Women with Diploid Androgenetic and Triploid Moles: A Proposed Mechanism for Mole Formation. Hum. Mol. Genet. 2009, 18, 888-897. [CrossRef] [PubMed]

106. Hayward, B.E.; De Vos, M.; Talati, N.; Abdollahi, M.R.; Taylor, G.R.; Meyer, E.; Williams, D.; Maher, E.R.; Setna, F.; Nazir, K.; et al. Genetic and Epigenetic Analysis of Recurrent Hydatidiform Mole. Hum. Mutat. 2009, 30, E629-E639. [CrossRef]

107. Xu, Y.; Qian, Y.; Liu, Y.; Wang, Q.; Wang, R.; Zhou, Y.; Zhang, C.; Pang, Z.; Ye, H.; Xue, S.; et al. A Novel Homozygous Variant in NLRP5 Is Associate with Human Early Embryonic Arrest in a Consanguineous Chinese Family. Clin. Genet. 2020, 98, 69-73. [CrossRef]

108. Begemann, M.; Spengler, S.; Kanber, D.; Haake, A.; Baudis, M.; Leisten, I.; Binder, G.; Markus, S.; Rupprecht, T.; Segerer, H.; et al. Silver-Russell Patients Showing a Broad Range of ICR1 and ICR2 Hypomethylation in Different Tissues. Clin. Genet. 2011, 80, 83-88. [CrossRef]

109. Bens, S.; Kolarova, J.; Beygo, J.; Buiting, K.; Caliebe, A.; Eggermann, T.; Gillessen-Kaesbach, G.; Prawitt, D.; Thiele-Schmitz, S.; Begemann, M.; et al. Phenotypic Spectrum and Extent of DNA Methylation Defects Associated with Multilocus Imprinting Disturbances. Epigenomics 2016, 8, 801-816. [CrossRef]

110. Cubellis, M.V.; Pignata, L.; Verma, A.; Sparago, A.; Del Prete, R.; Monticelli, M.; Calzari, L.; Antona, V.; Melis, D.; Tenconi, R.; et al. Loss-of-Function Maternal-Effect Mutations of PADI6 Are Associated with Familial and Sporadic Beckwith-Wiedemann Syndrome with Multi-Locus Imprinting Disturbance. Clin. Epigenetics 2020, 12, 139. [CrossRef] 